\title{
Transesterification by Reactive Distillation for Synthesis and Characterization of Biodiesel
}

\author{
G.B.Shinde ${ }^{1}$, V.S.Sapkal ${ }^{2}$, R.S.Sapkal ${ }^{3}$ and N.B.Raut ${ }^{4}$ \\ ${ }^{1}$ Department of Chemical Engineering, \\ Sir Visvesvaraya Institute of Technology, Nashik, M.S., \\ ${ }^{2}$ Sant Tukadoji Maharaj Nagpur University, Nagpur, M.S., \\ ${ }^{3}$ University Department of Chemical Technology, \\ Sant Gadgebaba Amravati University, Amravati, M.S., \\ ${ }^{4}$ Faculty of Engineering, Sohar University, Sultanate of Oman, \\ 1,2,3 India \\ ${ }^{4}$ Oman
}

\section{Introduction}

Rising world fuel prices, the growing demand for energy, and concerns about global warming are the key factors driving renewed interest in renewable energy sources and in bioenergy. Nowadays, the world energy demand has increased significantly due to the global industrialization and increase of population. As a result, the current limited reservoirs will soon be depleted at the current rate of consumption. So, the research in energy focuses on finding an alternative source of energy to the petroleum derived diesel.

India imported about 2/3rd of its petroleum requirement last year, which involved a cost of approximately Rs. 80,000 crores in foreign exchange. Even 5\% replacement of petroleum fuel by bio-fuel can help India and save Rs. 4000 corers per year in foreign exchange. It is utmost important that the options for substitution of petroleum fuels be explored to control this import bill. Biodiesel is a suitable substitute for petroleum-derived diesel. It is biodegradable, almost sulfur less and a renewable fuel, though still not produced by environmentally friendly routes. This alternative fuel consists of methyl or ethyl esters, a result of either transesterification of triglycerides (TG) or esterification of free fatty acids (FFAs). Biodiesel fuel has become more attractive because of its environmental benefits, due to the fact that plants and vegetable oils and animal fats are renewable biomass sources.

Currently, most of the biodiesel comes up from transesterification of edible resources such as animal fats, vegetable oils, and even waste cooking oils, under alkaline catalysis conditions. However, the high consumption of catalysts, the formation of soaps, and the low yields, make biodiesel currently more expensive than petroleum-derived fuel. In addition, the plants from which the vegetable oils are produced capture more $\mathrm{CO}_{2}$ from the atmosphere than the amount that these oils release during their combustion [1].

The three basic routes to biodiesel production from oils and fats are Base catalyzed transesterification of the oil, Direct acid catalyzed transesterification of the oil and conversion of the oil to its fatty acids and then to biodiesel. Out of these three routes the major production of biodiesel is done with the base catalyzed reaction process. 
The stoichiometric equation for transesterification reaction [9] in general can be represented as follows:

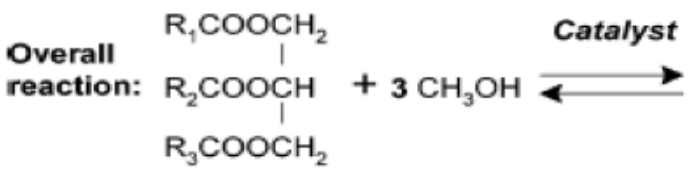

Triglyceride

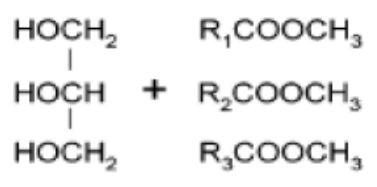

Glycerol Methyl esters

(Biodiesel)

\section{Biodiesel scenarios worldwide}

\begin{tabular}{|c|l|c|c|c|c|c|}
\hline Sr.No & Region/Country & $\mathbf{2 0 0 5}$ & $\mathbf{2 0 0 6}$ & $\mathbf{2 0 0 7}$ & $\mathbf{2 0 0 8}$ & $\mathbf{2 0 0 9}$ \\
\hline 1 & North America & 6.1 & 17.1 & 33.7 & 45.9 & 35.2 \\
\hline 2 & United States & 5.9 & 16.3 & 32.0 & 44.1 & 32.9 \\
\hline 3 & Central and south America & 0.5 & 2.2 & 15.2 & 38.6 & 57.9 \\
\hline 4 & Brazil & 0.0 & 1.2 & 7.0 & 20.1 & 27.7 \\
\hline 5 & Europe & 68.1 & 113.2 & 137.5 & 155.0 & 172.6 \\
\hline 6 & France & 8.4 & 11.6 & 18.7 & 34.4 & 41.1 \\
\hline 7 & Germany & 39.0 & 70.4 & 78.3 & 61.7 & 51.2 \\
\hline 8 & Italy & 7.7 & 11.6 & 9.2 & 13.1 & 13.1 \\
\hline 9 & Eurasia & 0.3 & 0.3 & 0.7 & 2.5 & 3.8 \\
\hline 10 & Lithuania & 0.1 & 0.2 & 0.5 & 1.3 & 1.9 \\
\hline 11 & Asia and Oceania & 2.2 & 9.1 & 15.8 & 28.8 & 38.5 \\
\hline 12 & China & 0.8 & 4.0 & 6.0 & 8.0 & 8.0 \\
\hline 13 & India & 0.2 & 0.4 & 0.2 & 0.2 & 0.4 \\
\hline 14 & Korea South & 0.2 & 0.6 & 1.7 & 3.2 & 5.0 \\
\hline 15 & Malaysia & 0.0 & 1.1 & 2.5 & 4.5 & 5.7 \\
\hline 16 & Thailand & 0.4 & 0.4 & 1.2 & 7.7 & 10.5 \\
\hline \multicolumn{2}{|c|}{ WORLD } & 77.2 & 142.0 & 202.9 & 270.9 & 308.2 \\
\hline
\end{tabular}

Source- U.S. Energy Information Administration, International Energy Statistics, Biofuels Production

Table 1. World biodiesel productions by region and selected countries 2005-2009 (Thousand barrels per day)

\section{Reactive distillation}

Reactive distillation is a chemical unit operation in which chemical reaction and product separation occurs simultaneously in one unit. Reactive distillation column consists of a reactive section in the middle with non-reactive rectifying and stripping sections at the top and bottom.

Let us begin by considering a reversible reaction scheme where $\mathrm{A}$ and $\mathrm{B}$ react to give $\mathrm{C}$ and D. The boiling point of the components follows the sequence A, C, D and B. The traditional flow sheet for this process consists of a reactor followed by a sequence of distillation columns. The mixture of $\mathrm{A}$ and $\mathrm{B}$ is fed to the reactor, where the reaction takes place in the presence of a catalyst and reaches equilibrium. A distillation train is required to produce pure products $\mathrm{C}$ and $\mathrm{D}$. The unreacted components, $\mathrm{A}$ and $\mathrm{B}$, are recycled back to the reactor. 
The Reactive distillation technology offers many benefits as well as restrictions over the conventional process of reaction followed by distillation or other separation approaches. Reducing capital cost, higher conversion, improving selectivity, lower energy consumption, the reduction or elimination of solvents in the process and voidance of azeotropes are a few of the potential advantages offered by Reactive distillation. Conversion can be increased far beyond what is expected by the equilibrium due to the continuous removal of reaction products from the reactive zone. This helps to reduce capital and investment costs and may be important for sustainable development due to a lower consumption of resources.[7]

The fig.1 represents the general configuration of reactive distillation.

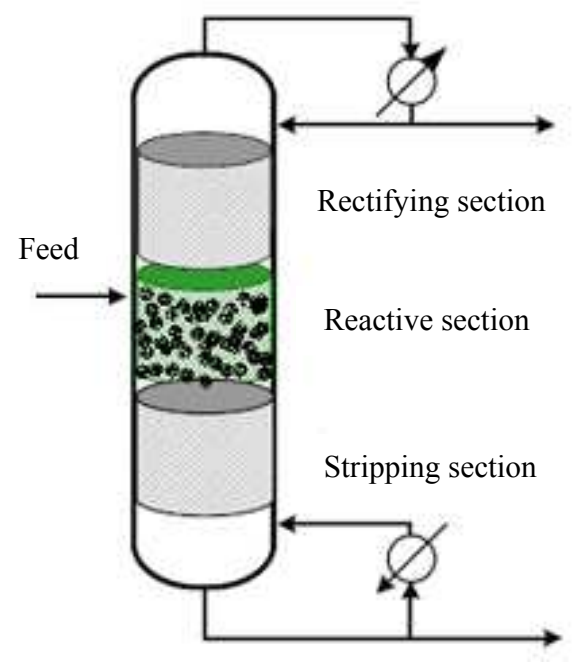

Fig. 1. The general configuration of Reactive Distillation

Based on the applied separation technology, reactive distillation, reactive extraction, reactive adsorption and other combined processes have been distinguished. The combined simultaneous performance of chemical reaction and a multi-component distillation process is an alternative, which has been increasingly used for the large-scale production of relevant chemicals. The use of reactive distillation process can have several advantages such as reduced downstream processing, utilization of heat of reaction for evaporation of liquid phase, simple temperature control of reactor, possibility of influencing chemical equilibria by removal of products and limitations imposed by azeotropic mixture. Several commercially important processes in reactive distillation have been identified in some recent reviews. [7]

Reactive distillation has been successfully applied for the etherification reaction to produce fuel ethers such as methyl tert-butyl ether (MTBE), tert-amyl methyl ether(TAME) and ethyl tertbutyl ether (ETBE). These have been the model reactions for the studies in reactive distillation in the last two decades. A small number of industrial applications of reactive distillation have been around for many decades. Low chemical equilibrium constants can be overcome and high conversions achieved by the removal of products from the location where the reaction is occurring. [6] 
It may be advantageous for liquid-phase reaction systems when the reaction must be carried out with a large excess of one or more of the reactants, when a reaction can be driven to completion by removal of one or more of the products as they are formed, or when the product recovery or by-product recycle scheme is complicated or made infeasible by azeotrope formation. Novel processes were proposed based on catalytic reactive distillation and reactive absorption to biodiesel production from esterification and transesterification reactions. The major benefits of this approach were: investment costs reducing about $45 \%$ energy savings compared to conventional reactive distillation, very high conversions, increased unit productivity, no excess of alcohol required and no catalyst neutralization step The advantage of reactive distillation can be summarized as follows [3]

a. Simplification: From design view point the combinations of reaction system and separation system can lead to significant capital saving.

b. Improved conversion of reactant approaches $100 \%$. This increase in conversion gives a benefit in reduced recycle costs.

c. Improved selectivity: where, removing one of the products from the reaction mixture or maintaining a low concentration of one of the reagents can lead to reduction of the rates of side reactions and hence improved selectivity for the desired products.

d. Significantly reduced catalyst requirement for the same degree of conversion.

e. Avoidance of azeotropes: RD is particularly advantageous when the reactor product is a mixture of species that can form several azeotropes with each other. RD conditions can allow the azeotropes to be "reacted away" in a single vessel.

f. There is a reduced by-product formation.

g. Heat integration benefits: If the reaction is exothermic, the heat of reaction can be used to provide the heat of vaporization and reduce the reboiler duty.

h. Removal of the product from a system at equilibrium will cause more products to form. Therefore reactive distillation is capable to increase the conversion of equilibrium limited reaction.

\section{Biodiesel production by reactive distillation}

As the reaction and separation occurs simultaneously in the same unit in reactive distillation, it is attractive in those systems where certain chemical and phase equilibrium conditions exist. Because there are many types of reactions, there are many types of reactive distillation columns. In this section we describe the ideal classical situation, which will serve to outline the basics of reactive distillation. Consider the system in which the chemical reaction involves two reactants (A and $B$ ) producing two products $(C$ and $D)$. The reaction takes place in the liquid phase and is reversible.

$$
\mathrm{A}+\mathrm{B} \leftrightarrow \mathrm{C}+\mathrm{D}
$$

The number of the separation steps depends on the number of products, catalysts, solvents as well as reactants which are not converted. The main objective functions to increase process economics are selectivity as well as reaction yield what influences the reactor design.

Usually, each unit operation is typically performed in individual items of equipment, which, when arranged together in sequence, make up the complete process plant. As reaction and separation stages are carried out in discrete equipment units, equipment and energy costs are added up from these major steps. However, this historical view of plant design is now being challenged by seeking for combination of two or more unit operations into the one plant unit [4]. 


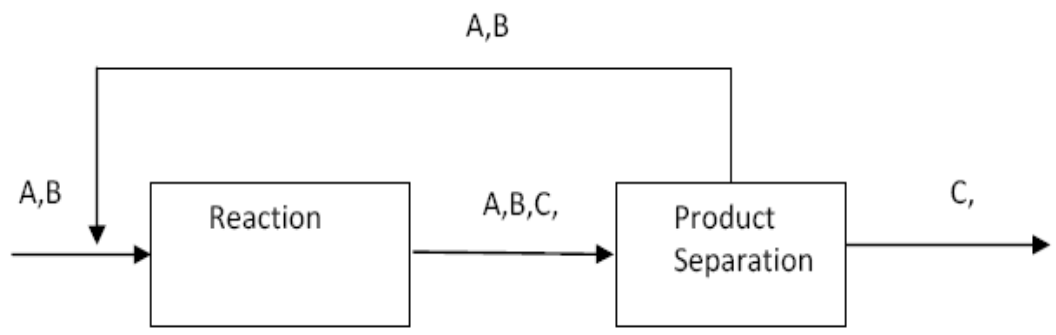

Fig. 2. Standard process scheme for reversible reactions in which the conversion is limited by the chemical equilibrium [9]

For reactive distillation to work, we should be able to remove the products from the reactants by distillation. This implies that the products should be lighter and/or heavier than the reactants. In terms of the relative volatilities of the four components, an ideal case is when one product is the lightest and the other product is the heaviest, with the reactants being the intermediate boiling components.

$$
a C>a D>a D
$$

The most obvious way to improve the reaction yield in an integrated unit is a continuous separation of one product out of the reaction zone. This allows for getting a $100 \%$ conversion in case of reversible reactions [9].

$$
\mathrm{A}+\mathrm{B} \leftrightarrow \mathrm{C}+\mathrm{D}
$$

A, B

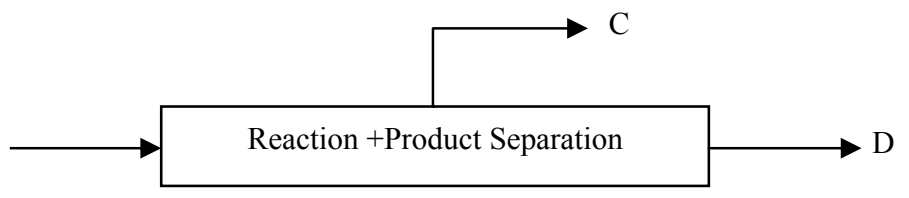

Fig. 3. Complete conversions of reactants in case of equilibrium reaction [7]

Figure 4 presents the flow sheet of this ideal reactive distillation column. In this situation the lighter reactant $\mathrm{A}$ is fed into the lower section of the column but not at the very bottom. The heavier reactant $B$ is fed into the upper section of the column but not at the very top. The middle of the column is the reactive section and contains number of reaction trays. The vapor flow rates through the reaction section change from tray to tray because of the heat of the reaction. As component A flows up the column, it reacts with descending B. Very light product $C$ is quickly removed in the vapor phase from the reaction zone and flows up the column. Likewise, very heavy product $D$ is quickly removed in the liquid phase and flows down the column. The section of the column above where the fresh feed of B is introduced (the rectifying section with NR trays) separates light product $C$ from all of the heavier components, so a distillate is produced that is fairly pure product $\mathrm{C}$. 


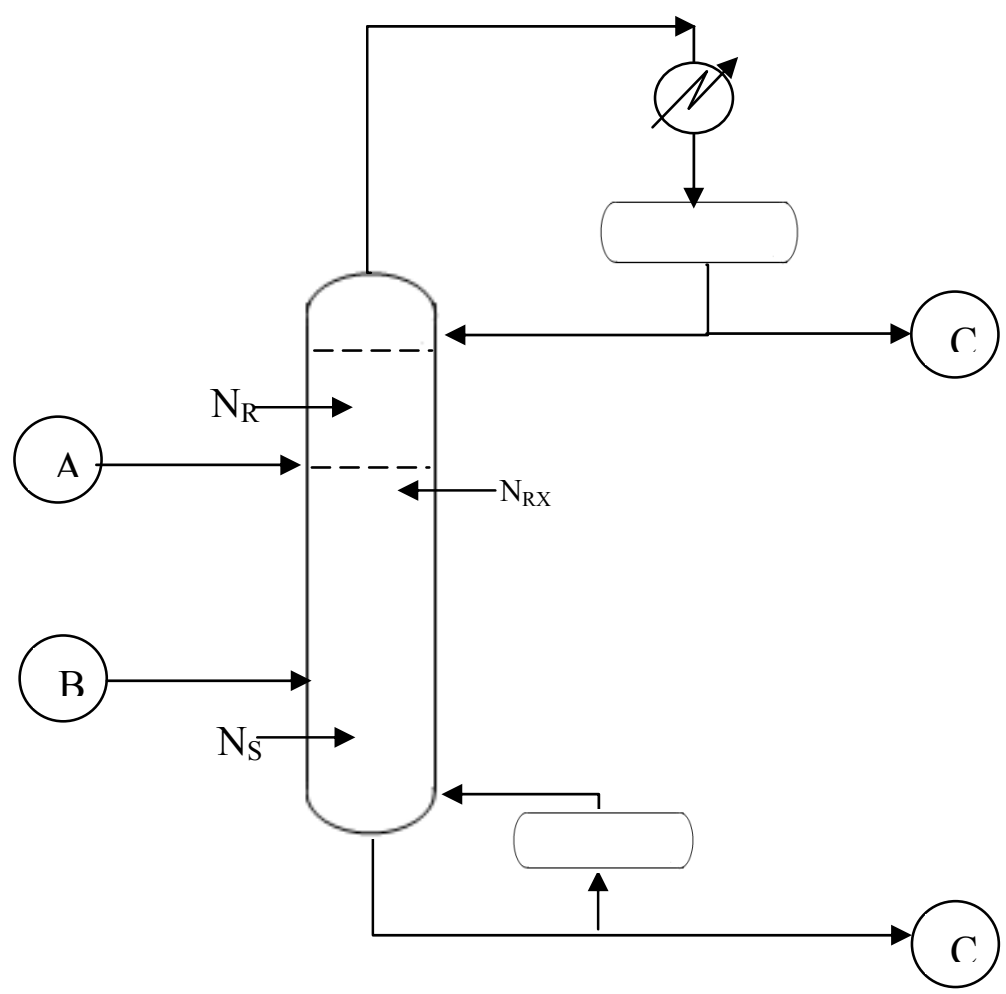

Fig. 4. Flow sheet of ideal reactive distillation column

The section of the column below where the fresh feed of $\mathrm{A}$ is introduced (the stripping section with NS trays) separates heavy product D from all of the lighter components, so a bottom is produced that is fairly pure product $\mathrm{D}$. The reflux flow rate and the reboiler heat input can be manipulated to maintain these product purities. The specific numerical case has 30 total trays, consisting of 10 stripping trays, 10 reactive trays, and 10 rectifying trays. Trays are numbered from the bottom. Note that the concentrations of the reactants peak at their respective feed trays. The purities of the two products are both $95 \mathrm{~mol} \%$, with B the major impurity in the bottoms and A the major impurity in the distillate [7].

Reactive distillation column must be adjusted to achieve these specifications while optimizing some objective function such as total annual cost (TAC). These design degrees of freedom include pressure, reactive tray holdup, number of reactive trays, location of reactant feed streams, number of stripping trays, number of rectifying trays, reflux ratio, and reboiler heat input [9].

Tray holdup is another design aspect of reactive distillation that is different from conventional. Holdup has no effect on the steady-state design of a conventional column. It certainly affects dynamics but not steady-state design. Column diameter is determined from maximum vapor loading correlations after vapor rates have been determined that achieve the desired separation. Typical design specifications are the concentration of the heavy key component in the distillate and the concentration of the light key component in the bottoms. 
However, holdup is very important in reactive distillation because reaction rates directly depend on holdup (or the amount of catalyst) on each tray. This means that the holdup must be known before the column can be designed and before the column diameter is known. As a result, the design procedure for reactive distillation is iterative. A tray holdup is assumed and the column is designed to achieve the desired conversion and product purities. The diameter of the column is calculated from maximum vapor-loading correlations. Then the required height of liquid on the reactive trays to give the assumed tray holdup is calculated. Liquid heights greater than 10-15 cm are undesirable because of hydraulic pressure drop limitations. Thus, if the calculated liquid height is too large, a new and smaller tray holdup is assumed and the design calculations repeated. An alternative, which may be more expensive in terms of capital cost, is to make the column diameter larger than that required by vapor loading [9].

\section{Case study - Transesterification by reactive distillation for synthesis and characterization of biodiesel}

\subsection{Materials and methods}

\section{Materials:}

a. Oil Feed stocks:

In this study, three commercially available feed stocks of vegetable oils are used .They are

1. Castor seed oil

2. Cottonseed oil

3. Coconut oil

\begin{tabular}{|c|c|c|c|c|c|}
\hline Sample & $\begin{array}{c}\text { Kinematic Viscosity, } \\
\text { cst }\left(\mathrm{mm}^{2} / \mathrm{s}\right)\end{array}$ & $\begin{array}{c}\text { Density } \\
\left(\mathrm{Kg} / \mathrm{m}^{3} \text { at }\right. \\
288 \mathrm{~K})\end{array}$ & $\begin{array}{c}\text { Flash point } \\
{ }^{\circ} \mathrm{C}\end{array}$ & $\begin{array}{c}\text { Pour point } \\
{ }^{\circ} \mathrm{C}\end{array}$ & $\begin{array}{c}\text { Saponification } \\
\text { value }\end{array}$ \\
\hline Castor oil & $115\left(\right.$ at $\left.60^{\circ} \mathrm{C}\right)$ & 938 & 229 & -33 & 182 \\
\hline Coconut oil & $24.85\left(\right.$ at $\left.40^{\circ} \mathrm{C}\right)$ & 907 & 225 & 20 & 191.1 \\
\hline Cottonseed oil & $35.42\left(\right.$ at $\left.40^{\circ} \mathrm{C}\right)$ & 904 & 15 & -15.5 & 192 \\
\hline
\end{tabular}

Table 2. Physical Properties of Vegetable Oil Feed stocks Used For Transesterification

b. Methanol:

Methanol (Merck) of $99.5 \%$ purity (density: $0.785 \mathrm{~g} / \mathrm{mL}$ at $30^{\circ} \mathrm{C}$ ) was used in this transesterification process.

c. Catalyst:

In this study the catalysts used are:

1. Homogeneous base catalysts $(\mathrm{KOH} \& \mathrm{NaOH})$

2. Heterogeneous solid acid catalysts (Amberlyst 15)

The two homogeneous basic catalysts $(\mathrm{KOH} \& \mathrm{NaOH})$ used for reactive distillation were purchased from local Chemical store at Amravati. M.S.The heterogeneous catalyst used for transesterification Amberlyst BD15 was purchased from Dayo Scientific Laboratory, Nashik Road, Nashik, M.S. India.

\section{Amberlyst-15:}

Amberlyst 15 wet is a macro reticular, strongly acidic, polymeric catalyst. Its continuous open pore structure makes it an excellent heterogeneous acid catalyst for a wide variety of organic reactions. Amberlyst 15 is extremely resistant to mechanical and thermal shocks. It 
also possesses greater resistance to oxidants such as chloride, oxygen and chromates than most other polymeric catalyst. It can use directly in the aqueous system or in organic medium after conditioning with a water miscible solvent. Amberlyst 15 has optimal balance of surface area, acid capacity and pore diameter to make it the catalyst of choice for esterification reactions.

\begin{tabular}{|l|l|}
\hline Physical forms & Opaque beads \\
\hline Ionic form as shipped & Hydrogen \\
\hline Total exchange capacity & $\geq 1.7 \mathrm{eq} / \mathrm{L}$ \\
\hline Moisture holding capacity & $52-57 \%$ \\
\hline Harmonic mean size & $600-850 \mu \mathrm{m}$ \\
\hline Fine contents & $<0.355 \mathrm{~mm}: 1.0 \%$ \\
\hline Coarse beads & $>1.180 \mathrm{~mm}: 5.0 \%$ \\
\hline Average pore diameter & $24 \mathrm{~nm}$ \\
\hline Surface area & $45 \mathrm{~m}^{2} / \mathrm{gm}$ \\
\hline Shrinkage water to methanol & $4.0 \%$ \\
\hline
\end{tabular}

Table 3. Characteristics of Amberlyst-15 catalyst

\subsection{Transesterification}

Transesterification also called alcoholysis is the most common way to produce biodiesel. This involves a catalyzed chemical reaction between vegetable oil and an alcohol to yield fatty acid alkyl esters (i.e., biodiesel) and glycerol. Transesterification is the displacement of alcohol from an ester by another alcohol in a process similar to hydrolysis, except that an alcohol is employed instead of water. Triglycerides, as the main component of vegetable oil, consist of three long chain fatty acids esterified to a glycerol backbone. When triglycerides react with an alcohol (e.g., methanol), the three fatty acid chains are released from the glycerol skeleton and combine with the alcohol to yield fatty acid alkyl esters (e.g., fatty acid methyl esters or biodiesel). Glycerol is produced as a by-product.

The mechanism of transesterification can be represented as follows:

$$
\begin{aligned}
& \mathrm{CH}_{2}-\mathrm{OOC}-\mathrm{R}_{1} \\
& \mathrm{CH}-\mathrm{OOC}-\mathrm{R}_{2}+3 R^{\prime} \mathrm{OH} \rightleftarrows \begin{array}{l}
\mathrm{R}_{2}-\mathrm{OOC}-\mathrm{R}^{\prime} \\
\mathrm{R}_{2}-\mathrm{OOC}-\mathrm{R}^{\prime}+\mathrm{CH}_{2}-\mathrm{OH} \\
\mathrm{CH}_{2}-\mathrm{OH} \\
\mathrm{R}_{3}-\mathrm{OOC}-\mathrm{R}^{\prime} \quad \mathrm{CH}_{2}-\mathrm{OH}
\end{array} \\
& \text { Triglyceride }+ \text { Alcohol } \stackrel{\text { Catalyst }}{\rightleftarrows} \text { Esters }+ \text { Glycerol }
\end{aligned}
$$

\subsubsection{Transesterification of vegetables oils}

In the transesterification of different types of oils, triglycerides react with an alcohol, generally methanol or ethanol, to produce esters and glycerin. To make it possible, a catalyst is added to the reaction. The overall process is normally a sequence of three consecutive steps, which are reversible reactions. In the first step, from triglycerides diglyceride is obtained, from diglyceride monoglyceride is produced and in the last step, from monoglycerides glycerin is obtained. In all these reactions esters are produced. The stoichiometric relation between alcohol and the oil is 3:1. However, an excess of alcohol is usually more appropriate to improve the reaction towards the desired product: 


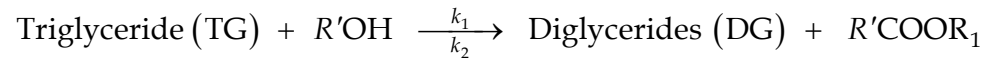

$$
\begin{aligned}
& \text { Diglycerides }(\mathrm{DG})+\mathrm{R}^{\prime} \mathrm{OH} \underset{k_{4}}{\stackrel{k_{3}}{\longrightarrow}} \text { Monoglycerides }(\mathrm{MG})+R^{\prime} \mathrm{COOR}_{1}
\end{aligned}
$$

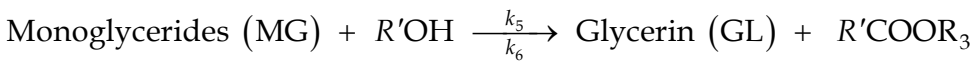

\section{Startup Procedures of transesterification using reactive distillation:}

To start of each experiment, approximate $2 \mathrm{~L}$ of oil and $250 \mathrm{~mL}$ of methanol were injected into the column. The reboiler heater was set to $120^{\circ} \mathrm{C}$ and allowed to heat for approximately 1.5 hours till the temperature of the top column reached $62^{\circ} \mathrm{C}$.

\section{Steady-operation:}

The inputs, both oil at $55^{\circ} \mathrm{C}$ and methanol at $30^{\circ} \mathrm{C}$, were pumped into a short tube mixer to mix the oil with the methanol/catalyst solution. Then the reactant mixture at $62^{\circ} \mathrm{C}$ was entered to the top of the RD column. In the RD column, triglyceride in the reactant mixture further reacted with the present methanol. The product mixture was withdrawn from the reboiler section and sent to a glycerol ester separator, where the glycerol and esters were separated by gravity in a continuous mode. Every hour, samples were collected from reboiler to analyze the biodiesel composition and methanol content.

In this experimentation reaction parameters has been optimized and an optimized process has been investigated for biodiesel production by transesterification of vegetable oil using reactive distillation technique

\section{Calculations:}

The ester content $(C)$ expressed as a fraction in percent, is calculated using the following formula:

$$
C=\frac{\left(\sum A\right)-A_{E I}}{A_{E I}} \times \frac{C E I \times V E I}{m} \times 100 \%
$$

$\sum \mathrm{A}=$ the total peak area from the FAME $\mathrm{C}_{14: 0}$ to $\mathrm{C}_{24: 1}$

$\mathrm{A}_{\mathrm{EI}}=$ the peak area of methyl heptadecanoate

$\mathrm{C}_{\mathrm{EI}}=$ the concentration, in $\mathrm{mg} / \mathrm{ml}$ of the methyl heptadecanoate solution

$\mathrm{V}_{\mathrm{EI}}=$ the volume, in $\mathrm{ml}$ of the methyl heptadecanoate solution

$\mathrm{m}=$ the mass, in $\mathrm{mg}$ of the sample

\section{Experimental setup}

The system consists of a reactive distillation column fed at the top with the initial reactive solution (oil, alcohol, catalyst). This solution slowly travels down between the plates. When the solution exits the column; the alcohol that has not reacted is recuperated by evaporation. Then, the vapors are re-circulated in the reactive distillation column in the upward direction passing through the plates. As the vapors travel through, interactions between the gaseous alcohol and the liquid solution occur. This then would increase the effective oil to alcohol ratio up to 20:1 (He, Singh et al.2006), thus shifting the reaction equilibrium to the product side and therefore increasing the reaction efficiency. Finally, once the alcohol vapors have reached the top of the reactive distillation column, they are condensed through a condenser 
allowing the remaining alcohol fraction to re-enter the system. The experimental setup is shown in fig. 5 below.

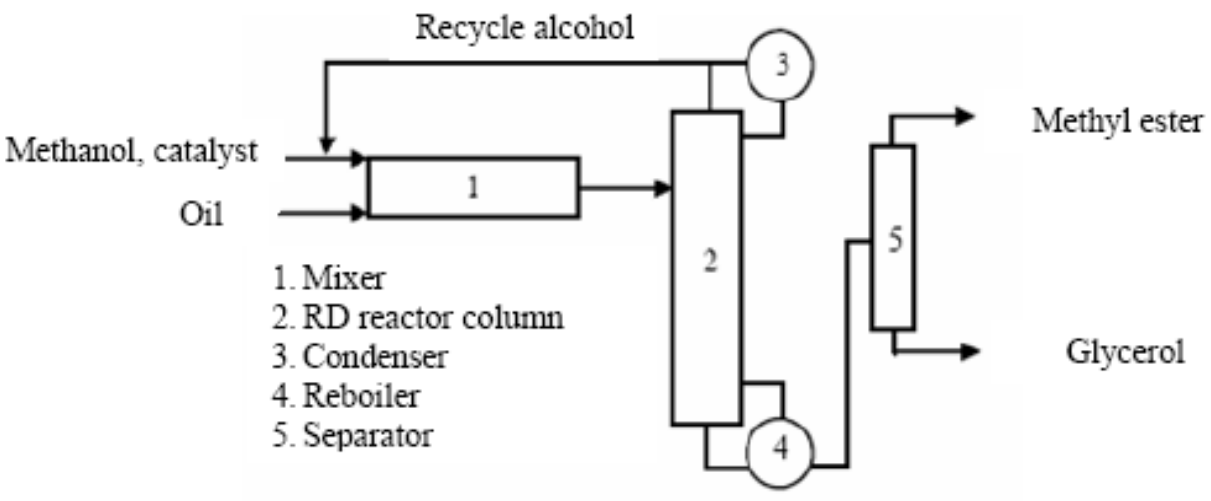

Fig. 5. Schematic of Reactive distillation column for biodiesel

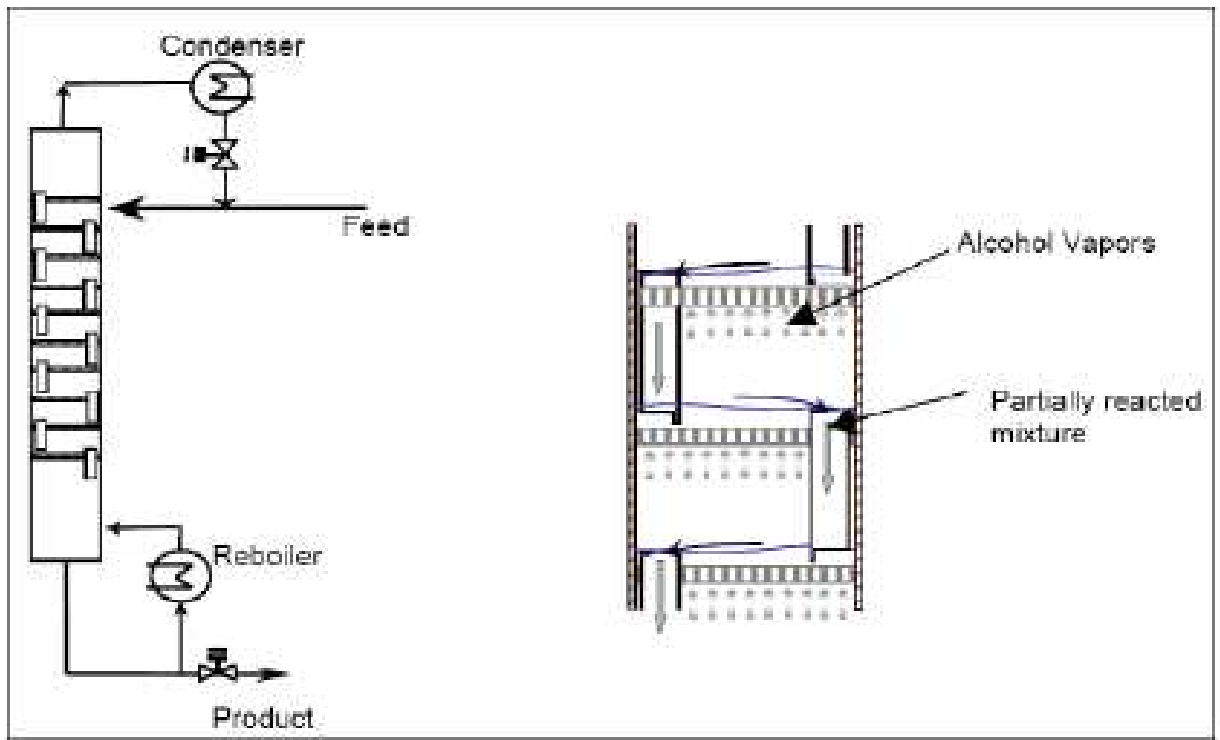

Singh, Thompson Et Al. 2004; Thompson and He 2007

Fig. 6. Operation in Reactive Distillation column 


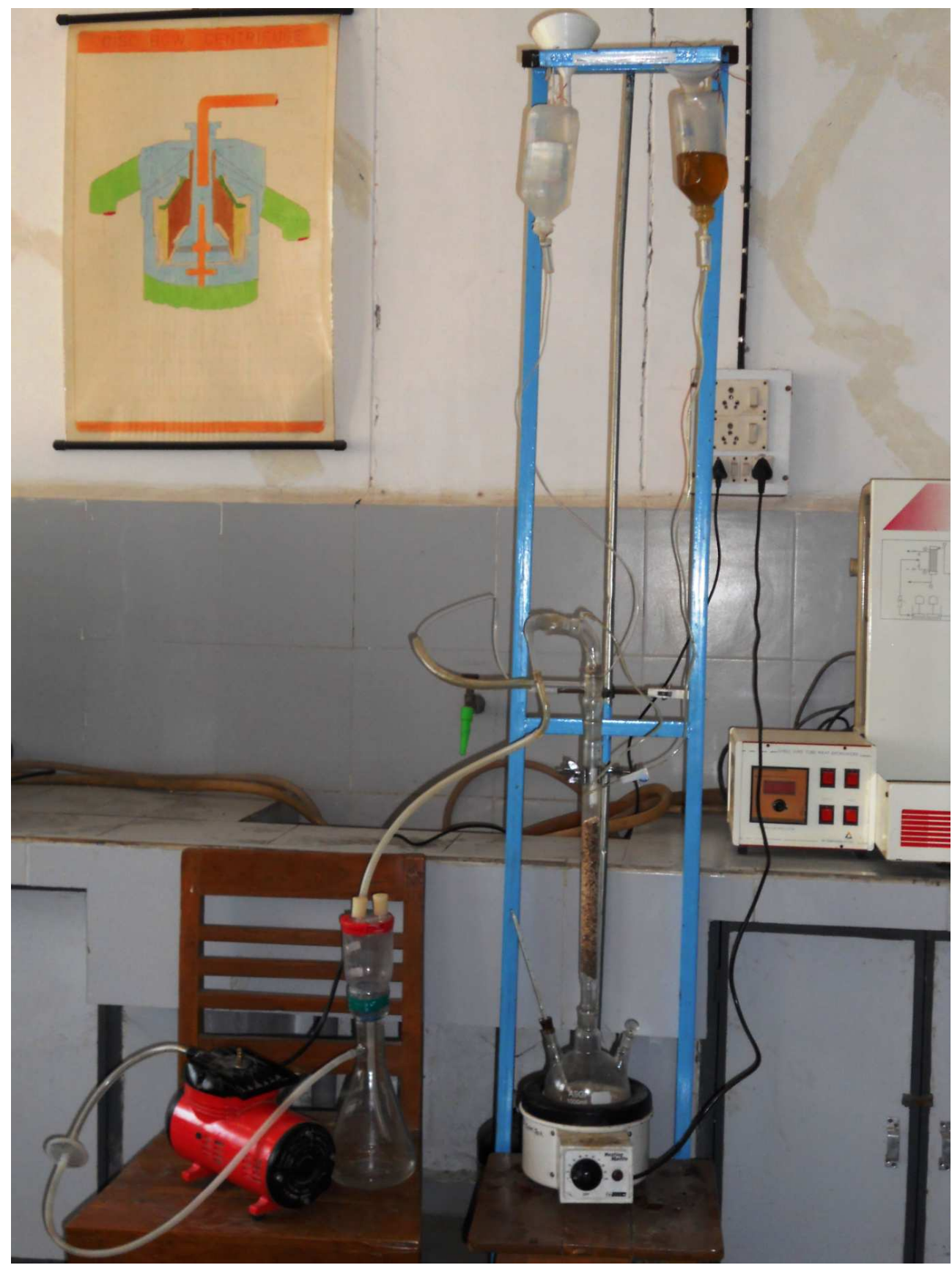

Fig. 7. a) View of experimental lab apparatus of Reactive distillation 


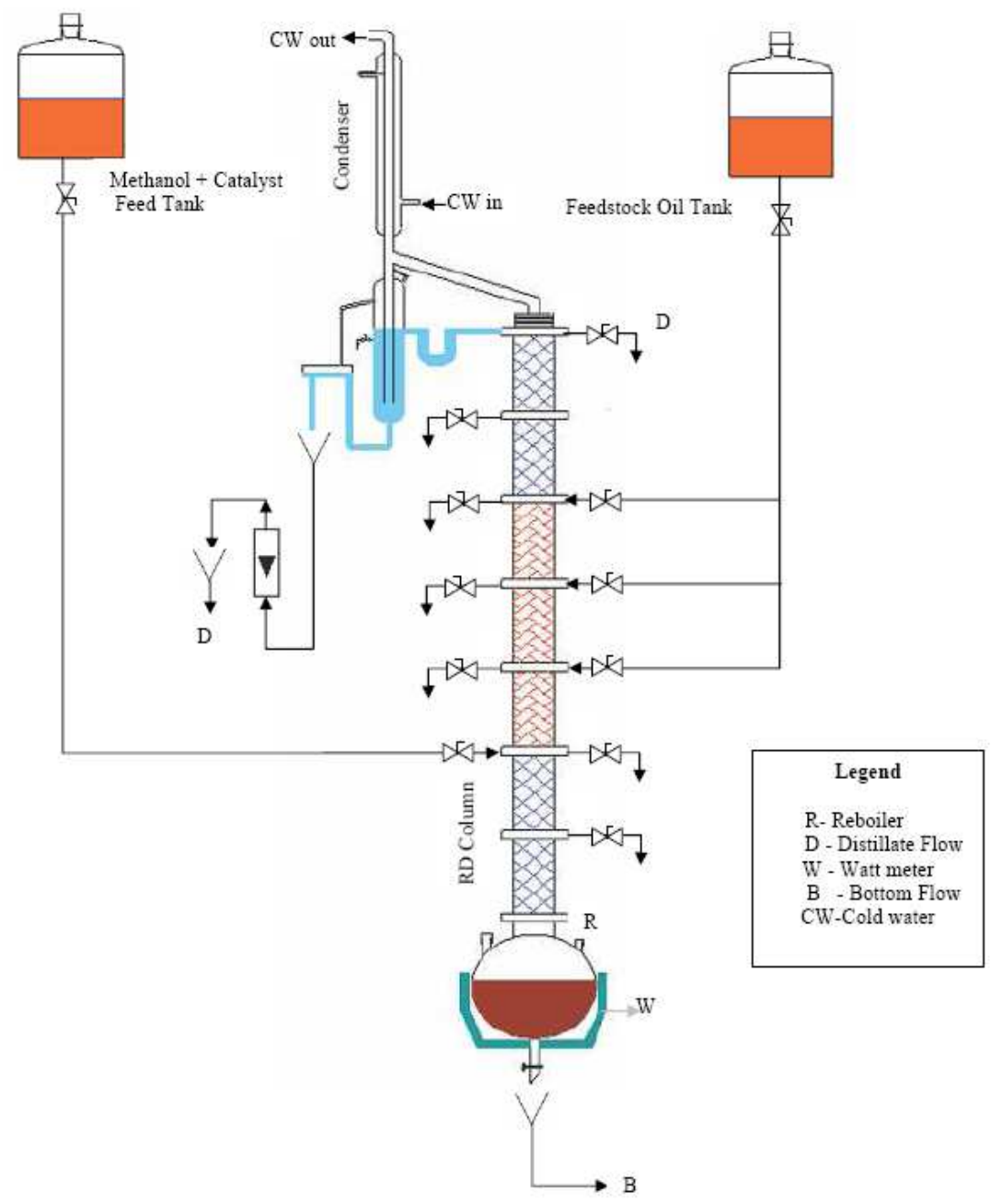

Fig. 7. b) Schematic Diagram of Experimental Setup of Continuous Reactive Distillation Column for biodiesel

In the present experimental study, packed bed Lab-scale reactive distillation column is designed and constructed. This column made up of glass (Inner dia: $30 \mathrm{~mm}$, Height of column: $210 \mathrm{~mm}$ ) has been used. The RD column packings used were glass packing. The feed reactants entering into the column were distributed over the packings by the use of distributor plates. The process parameters studied here are alcohol-to-oil ratio. $\{3: 1,4: 1$ and 9:1, Optimum methanol-to-oil molar ratio $=4: 1\}$,Flow rates of reactants $\{2,4,6 \mathrm{ml} / \mathrm{min}$, Optimum flow rate $=4 \mathrm{ml} / \mathrm{min}\}$, Reaction time $\{$ Residence time of $2 \mathrm{~min}, 3 \mathrm{~min}$., $6 \mathrm{~min}$, optimum residence time $=3 \mathrm{~min}\}$, Temperature $\left\{55,60,65^{\circ} \mathrm{C}\right.$, Optimum temperature $\left.=65^{\circ} \mathrm{C}\right\}$.

The RD reactor consists of perforated plates or packed sections. For packed columns the packing holds certain amount of reacting liquid in it, forming mini-reactors. Un-reacted 
alcohol is vaporized from the reboiler, flows upward constantly, and bubbles through the liquid in the packing, which provides a uniform mixing. The thru-vapor is condensed at the top of the RD column and refluxes partially back to the column and the rest combines with the feeding stream

In this study, three non edible vegetable oils namely, castor seed oil, coconut oil and cottonseed oil were used one by one for transesterification.

\subsection{Physical and chemical characteristics of the feedstock vegetable oils used for the production of biodiesel}

\begin{tabular}{|l|c|c|c|c|c|}
\hline \multicolumn{1}{|c|}{ Sample } & $\begin{array}{c}\text { Kinematic } \\
\text { Viscosity, } \\
\mathrm{cst}\left(\mathrm{mm}^{2} / \mathrm{s}\right)\end{array}$ & $\begin{array}{c}\text { Density } \\
\left(\mathrm{Kg} / \mathrm{m}^{3} \text { at }\right. \\
288 \mathrm{~K})\end{array}$ & $\begin{array}{c}\text { Flash point } \\
{ }^{\circ} \mathrm{C}\end{array}$ & $\begin{array}{c}\text { Pour point } \\
{ }^{\circ} \mathrm{C}\end{array}$ & $\begin{array}{c}\text { Saponification } \\
\text { value }\end{array}$ \\
\hline Castor oil & $115\left(\right.$ at $\left.60^{\circ} \mathrm{C}\right)$ & 938.8 & 229 & -33 & 182 \\
\hline Cottonseed oil & $35.42\left(\right.$ at $\left.40^{\circ} \mathrm{C}\right)$ & 904 & 15 & -15.5 & 192 \\
\hline Coconut oil & $24.85\left(\right.$ at $\left.40^{\circ} \mathrm{C}\right)$ & 907 & 225 & 20 & 191.1 \\
\hline
\end{tabular}

Table 4. Physical Properties of Vegetable Oil Feed stocks Used for Transesterification:

\begin{tabular}{|l|c|c|c|c|c|c|c|}
\hline \multicolumn{1}{|c|}{ Oil Sample } & $\begin{array}{c}\text { Palmitic } \\
\text { acid(16:0) }\end{array}$ & $\begin{array}{c}16: 1 \\
\text { (Palmitoleic) }\end{array}$ & $\begin{array}{c}\text { Stearic } \\
\text { acid(18:0) }\end{array}$ & $\begin{array}{c}\text { Oleic acid } \\
(18: 1)\end{array}$ & $\begin{array}{c}\text { Linoleic } \\
\text { acid (18:2) }\end{array}$ & $\begin{array}{c}\text { Linolenic } \\
\text { acid (18:3) }\end{array}$ & Other \\
\hline Castor oila & 1.1 & 0 & 3.1 & 4.9 & 1.3 & 0 & 89.6 \\
\hline Cottonseed oil & 28.7 & 0 & 0.9 & 13.0 & 57.4 & 0 & 0 \\
\hline Coconut oil & 9.7 & 0.1 & 3.0 & 6.9 & 2.2 & 0 & 65.7 \\
\hline
\end{tabular}

Castor oil contains $89.6 \%$ ricinoloic acid

Table 5. Table Fatty acids composition of vegetable oils samples under consideration

Physical and chemical characteristics of castor oil

\begin{tabular}{|l|l|l|}
\hline Sr no. & Parameters & Values \\
\hline 1 & Appearance & Pale dark yellow \\
\hline 2 & Density $\left(\right.$ at $\left.15^{\circ} \mathrm{C}\right)$ & $938.8 \mathrm{~kg} / \mathrm{m}^{3}$ \\
\hline 3 & Iodine value & $82-90$ \\
\hline 4 & Saponification value & 182 \\
\hline 5 & Flash Point & $229{ }^{\circ} \mathrm{C}$ \\
\hline 6 & Pour point & $-33 \circ \mathrm{C}$ \\
\hline 7 & Acid value & $2.0 \mathrm{max}$ \\
\hline 8 & Moisture and Volatiles & $0.50 \% \mathrm{max}$ \\
\hline 9 & Specific gravity at $20^{\circ} \mathrm{C}$ & $0.954-0.967$ \\
\hline 10 & Kinematic Viscosity ,cst $\left(\mathrm{mm}^{2} / \mathrm{s}\right)$ & $115\left(\right.$ at $\left.60^{\circ} \mathrm{C}\right)$ \\
\hline & Fatty acids content $(\%)$ & \\
\hline 11 & Ricinoleic acid & 89.6 \\
\hline 12 & Linoleic acid & $4.2 \%$ \\
\hline 13 & Oleic acid & $3 \%$ \\
\hline 14 & Stearic acid & $1 \%$ \\
\hline 15 & Palmitic acid & $1 \%$ \\
\hline 16 & Linolenic acid & $0.3 \%$ \\
\hline
\end{tabular}

Table 6. Physical and chemical characteristics of castor oil 


\section{Physical and chemical characteristics of cottonseed oil}

Its fatty acid profile generally consists of $70 \%$ unsaturated fatty acids including $18 \%$ monounsaturated (oleic), 52\% polyunsaturated (linoleic) and 26\% saturated (primarily palmitic and stearic).

\begin{tabular}{|l|l|l|}
\hline Sr. no. & Parameters & Values \\
\hline 1 & Appearance & Golden yellow \\
\hline 2 & Density & 904 \\
\hline 3 & Kinematic viscosity $\left(\right.$ at $\left.40^{\circ} \mathrm{C}\right)$ & $35.42 \mathrm{cSt}$ \\
\hline 4 & Saponification value & 192 \\
\hline 5 & Flash point & $15^{\circ} \mathrm{C}$ \\
\hline 6 & Pour point & $-15.5^{\circ} \mathrm{C}$ \\
\hline 7 & Acid value & $0.6518 \mathrm{mg}$ of $\mathrm{KOH} / \mathrm{gm}$ of oil \\
\hline 8 & Free fatty acids & $0.3258 \%$ \\
\hline 9 & Molecular weight & 863 \\
\hline 10 & Specific gravity at $20^{\circ} \mathrm{C}$ & $0.9406 \mathrm{gm} / \mathrm{ml}$ \\
\hline
\end{tabular}

Table 7. Physical and chemical characteristics of cottonseed oil

\begin{tabular}{|l|l|l|}
\hline Sr no. & Parameters & Values \\
\hline 1 & Palmitic acid & $23 \%$ \\
\hline 2 & Oleic acid & $18 \%$ \\
\hline 3 & Linoleic acid & $52 \%$ \\
\hline 4 & Aleic acid & $19 \%$ \\
\hline 5 & Alpha lenoleic acid & $1 \%$ \\
\hline 6 & Stearic acid & $3 \%$ \\
\hline
\end{tabular}

Table 8. Fatty acids composition of cottonseed oil

Physical and chemical characteristics of coconut oil

\begin{tabular}{|l|l|l|}
\hline Sr no. & Parameters & Values \\
\hline 1 & Melting point $\left({ }^{\circ} \mathrm{C}\right)$ & 24 \\
\hline 2 & Moisture $\%$ & $<0.1$ \\
\hline 3 & Kinematic viscosity $\left(\mathrm{mm}^{2} / \mathrm{s}\right)$ & $24.85\left(\right.$ at $\left.40^{\circ} \mathrm{C}\right)$ \\
\hline 4 & Density $\left(\right.$ at $\left.15^{\circ} \mathrm{C}\right)$ & $\left.907 \mathrm{~kg} / \mathrm{m}^{3}\right)$ \\
\hline 3 & Iodine value $\left(\mathrm{cgI}_{2} / \mathrm{g}\right)$ & $12-15$ \\
\hline 5 & Saponification value & 191.1 \\
\hline 6 & Flash Point & $225 \circ \mathrm{C}$ \\
\hline 7 & Pour point & $20^{\circ} \mathrm{C}$ \\
\hline 8 & Total phenolics $(\mathrm{mg} / \mathrm{kg})$ & 620 \\
\hline Fatty acids content $(\%)$ & \multicolumn{2}{|l|}{} \\
\hline 9 & Saturates & 92.0 \\
\hline 10 & Monosaturates & 6.0 \\
\hline 11 & Polyunsaturates & 2.0 \\
\hline
\end{tabular}

Table 9. Physical and chemical characteristics of coconut oil 


\subsection{Continuous transesterification by reactive distillation for synthesis of biodiesel}

The process parameters studied here are alcohol-to-oil ratio.\{3:1, 6:1 and 9:1 ,Optimum methanol-to-oil molar ratio $=6: 1\}$, Reaction time $\{$ Residence time of $2 \mathrm{~min}, 3 \mathrm{~min} ., 6 \mathrm{~min}$, optimum residence time $=3 \mathrm{~min}\}$, Temperature $\left\{55,60,65^{\circ} \mathrm{C}\right.$, Optimum temperature $\left.=65^{\circ} \mathrm{C}\right\}$, catalyst loading (1,1.5 and $2 \%$ by wt of oil).

\subsubsection{Effect of methanol to oil molar ratio on methyl ester conversion}

Feedstock oil was held in a separate heated reservoir maintained at $50^{\circ} \mathrm{C}$.The methanol-to-oil molar ratios used were 3.0, 6.0 and 9.0. From several trials, it was found that an overall flow rate of $5-6 \mathrm{ml} / \mathrm{min}$ with the column temperature at $64^{\circ} \mathrm{C}$ provided residence time of about $6 \mathrm{~min}$ without any significant operational difficulties. The column temperature was maintained by controlling the reboiler heat input. Temperatures above $64^{\circ} \mathrm{C}$ caused excessive entrainment and a reduction in methanol concentrations in the liquid phase. In preparation for each trial, stock alcoholic $\mathrm{KOH}$ was prepared on a stirring plate at a ratio that corresponded to 1, 1.5 and $2 \% \mathrm{KOH} \mathrm{w} / \mathrm{w}$ of oil for each given methanol-to-oil molar ratio, and placed in a holding reservoir next to the RD column. Optimum reaction time in biodiesel formation (1min in prereactor $+5 \mathrm{~min}$ in $\mathrm{RD}$ column $=6 \mathrm{~min}$.). Reaction time by using $\mathrm{RD}$ column is 20 times shorter than that in typical batch processes. Also productivity of RD reactor system is 6 to 10 times higher than that of batch and existing continuous flow processes.

The main process parameters examined in this study were as shown below:

For individual oils (Castor, Cottonseed and Coconut oil) under consideration

\begin{tabular}{|c|c|c|c|}
\hline $\begin{array}{c}\text { Methanol/oil molar } \\
\text { Ratio (mol/mol) }\end{array}$ & $\begin{array}{c}\text { Methyl esters } \\
\text { Conversion } \\
(\%), \text { Castor oil }\end{array}$ & $\begin{array}{c}\text { Methyl esters } \\
\text { Conversion } \\
(\%), \text { Cottonseed oil }\end{array}$ & $\begin{array}{c}\text { Methyl esters } \\
\text { Conversion } \\
(\%), \text { Coconut oil }\end{array}$ \\
\hline 3 & 56 & 68 & 55 \\
\hline 6 & 68 & 72 & 88 \\
\hline 9 & 72 & 74 & 89 \\
\hline
\end{tabular}

Temperature $=64^{\circ} \mathrm{C}$, Flow rate $=6 \mathrm{ml} / \mathrm{min}$, Reaction time $=6 \mathrm{~min}$. , Catalyst $(\mathrm{KOH})=1 \%$ by wt. of oil $)$

Table 10. (a) Effect of Methanol to oil Molar ratio on methyl esters conversion

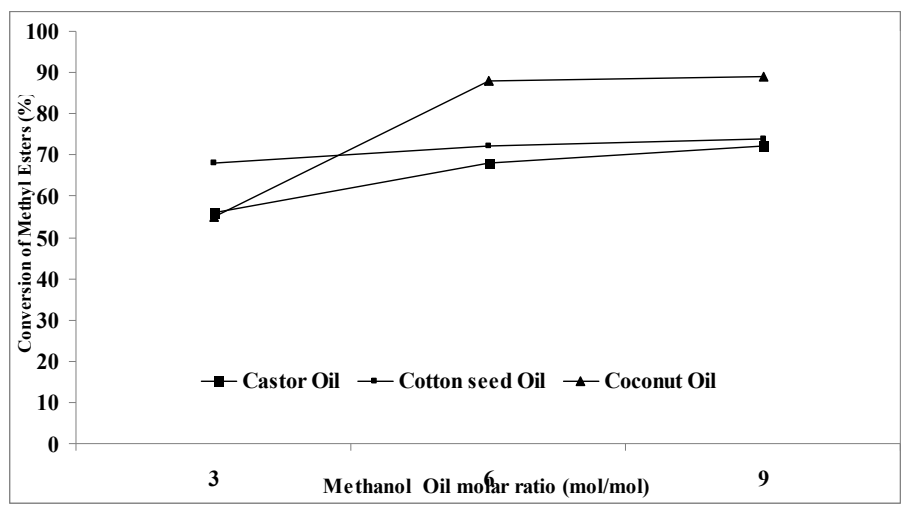

Optimum Molar ratio of Methanol- to- oil= 6:1

Fig. 8. Effect of Methanol to oil Molar ratio on methyl ester conversion 


\begin{tabular}{|c|c|c|c|}
\hline Reaction Time(min.) & $\begin{array}{c}\text { Methanol/oil molar Ratio } \\
(\mathrm{mol} / \mathrm{mol})=3\end{array}$ & $\begin{array}{c}\text { Methanol/oil molar } \\
\text { Ratio } \\
(\mathrm{mol} / \mathrm{mol})=6\end{array}$ & $\begin{array}{c}\text { Methanol/oil } \\
\text { molar Ratio } \\
(\mathrm{mol} / \mathrm{mol})=9\end{array}$ \\
\hline 2 & 68 & 72 & 55 \\
\hline 6 & 89 & 96 & 88 \\
\hline 8 & 91 & 94 & 89 \\
\hline
\end{tabular}

Reaction temperature $=60^{\circ} \mathrm{C}$, Catalyst concentration $=1 \mathrm{wt} \%$, Methanol to mixed oil molar ratio $=3: 1$, 6:1, 9:1

Table 10. (b) Effect of methanol-to-mixed oil feed molar ratio on methyl ester conversion

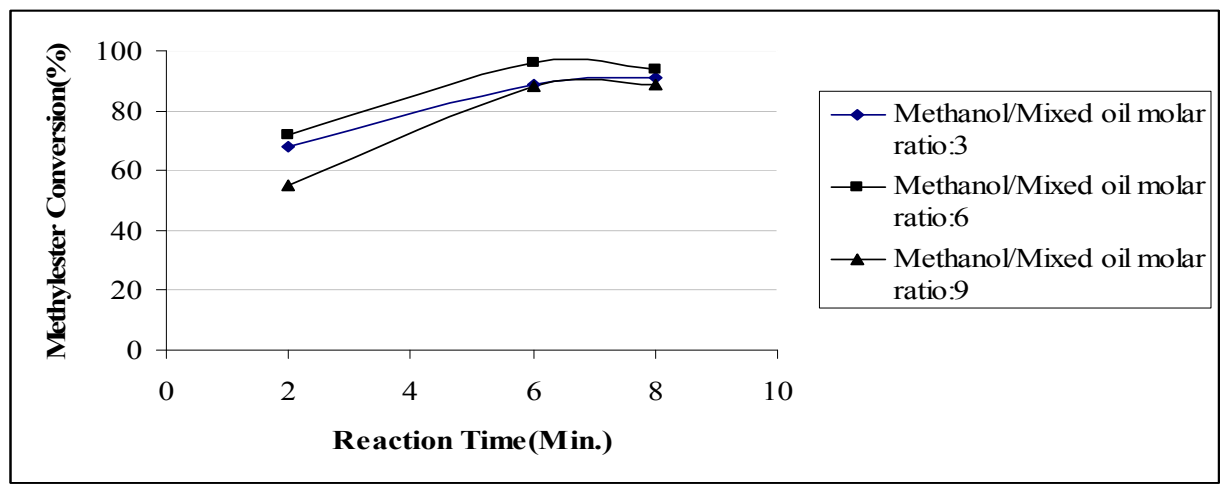

Fig. 9. Effect of Methanol to Mixed oil Molar ratio on methyl ester conversion

The three vegetable oil feedstock's under consideration were mixed and three mixed feed oils were prepared for the experimental runs. The effect of Methanol to Mixed oil Molar ratio on methyl ester conversion was observed as shown in fig.9. The conversion of methyl esters was found to increase with increase in molar ratio during initial reaction time. Also the highest conversion o e $6 \mathrm{~min}$ in RD column. Thus it can be concluded that the mixed oils can be used for synthesis of biodiesel. This would help in reduction in overall cost of biodiesel synthesis by cutting down the cost of expensive oil by replacing the portion of expensive oils by cheaper oils or the oils which are easily available in abundance.

\begin{tabular}{|c|c|c|c|}
\hline Reaction Time(min.) & $\begin{array}{c}\text { Methyl ester } \\
\text { conversion (\%) } \\
\text { Mixed oil 1 }\end{array}$ & $\begin{array}{c}\text { Methyl ester } \\
\text { conversion (\%) } \\
\text { Mixed oil 2 }\end{array}$ & $\begin{array}{c}\text { Methyl ester } \\
\text { conversion (\%) } \\
\text { Mixed oil 3 }\end{array}$ \\
\hline 2 & 65 & 77 & 78 \\
\hline 6 & 89 & 92 & 95 \\
\hline 8 & 90 & 93 & 95 \\
\hline
\end{tabular}

Reaction temperature $=60{ }^{\circ} \mathrm{C}$, Catalyst concentration $=1 \mathrm{wt} \%$, Methanol to mixed oil molar ratio $=6: 1$, Mixed oil 1= 50\% Castor oil $+50 \%$ Cottonseed oil, Mixed oil $2=50 \%$ Castor oil $+50 \%$ Coconut oil, Mixed oil $3=50 \%$ Coconut oil $+50 \%$ Cottonseed oil

Table 10. (c) Effect of reaction time using different mixed oils on methyl ester conversion 


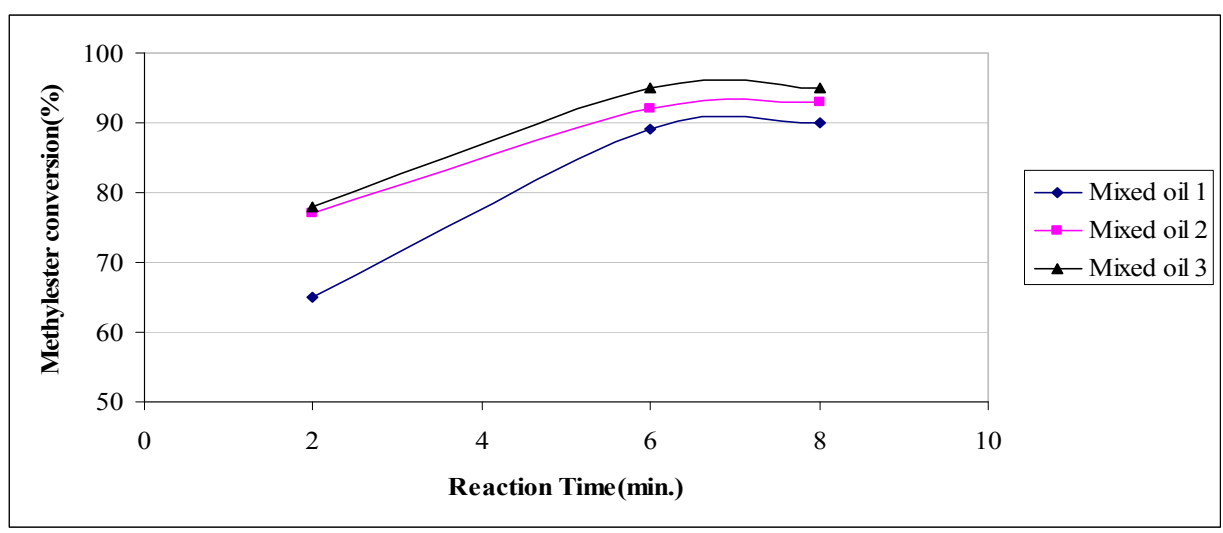

Fig. 10. Effect of reaction time using different mixed oils on methyl ester conversion It was observed that mixed oil 3 i.e. 50\% Coconut oil $+50 \%$ Cottonseed oil showed the maximum methyl ester conversion.

\subsubsection{Effect of flow rates on methyl ester conversion}

\begin{tabular}{|c|c|c|c|}
\hline $\begin{array}{c}\text { Flow rate, } \\
\mathrm{ml} / \mathrm{min}\end{array}$ & $\begin{array}{c}\text { Methyl esters } \\
\text { Conversion } \\
(\%), \text { Castor oil }\end{array}$ & $\begin{array}{c}\text { Methyl esters Conversion } \\
(\%), \text { Cottonseed oil }\end{array}$ & $\begin{array}{c}\text { Methyl esters } \\
\text { Conversion } \\
(\%), \text { Coconut oil }\end{array}$ \\
\hline 5 & 90 & 92 & 90 \\
\hline 6 & 94 & 96 & 93 \\
\hline 7 & 94 & 95 & 93 \\
\hline
\end{tabular}

Molar ratio of Methanol to Oil $=6: 1$, Reaction time $=6 \mathrm{~min}$., Catalyst $(\mathrm{KOH})=1 \%$ (by wt. of oil), Temperature $=60^{\circ} \mathrm{C}$

Table 11. Effect of Flow rates on methyl ester conversion

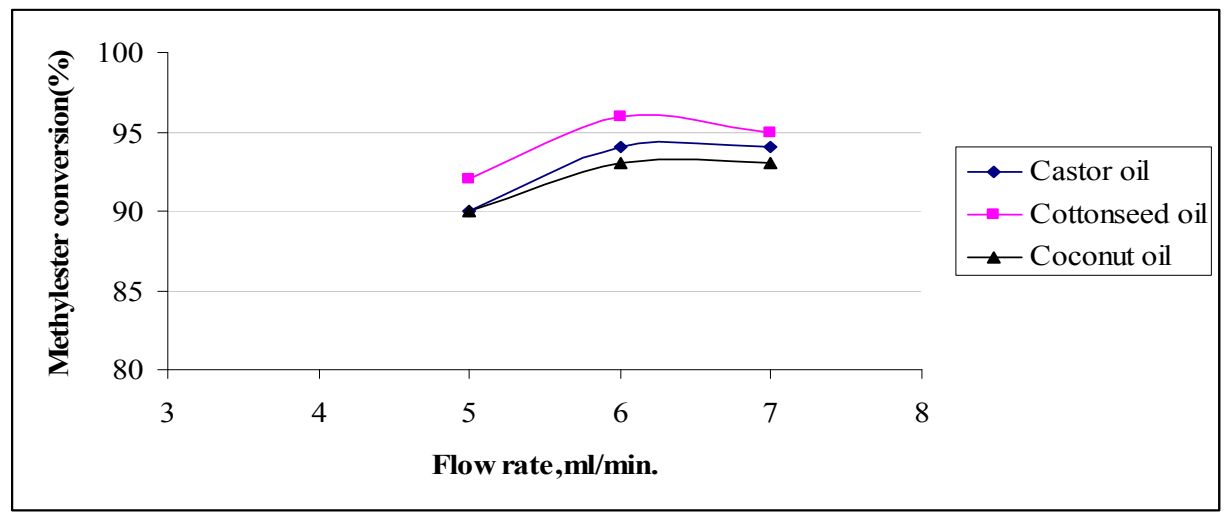

Optimum flow rate $=6 \mathrm{ml} / \mathrm{min}$

Fig. 11. Effect of Flow rates on methyl ester conversion 
The feed stream flow rates for the test run were chosen carefully in order to avoid any column flooding problem. The flow rate, which is inversely related to retention time, is used as an experimental factor to interpret the reaction conversion with the liquid retention time. The flow rate achieved in the experimental runs varied from 5 to $7 \mathrm{~mL} / \mathrm{min}$. The retention time varied from about 4 to $8 \mathrm{~min}$. These values may not be the actual reaction time because of some reaction that takes place in the reboiler. Since the concentrations of methanol and catalyst were very small in the liquid phase of the reboiler, it was not possible to determine the actual retention time of reactants and catalyst in the reboiler. The effect of flow rate was mainly on the production of methyl ester of the reactor. The \% weight of methyl ester decreased while the flow rate increased since the retention time is less. For the RD operation of setup in this study, the feed flow rate should not be higher $6 \mathrm{~mL} / \mathrm{min}$ in order to avoid flooding in column and this rate were considered as optimum range of operation.

\subsubsection{Effect of reaction time on methyl ester conversion}

\begin{tabular}{|c|c|c|c|}
\hline $\begin{array}{c}\text { Reaction Time } \\
(\mathrm{min} .)\end{array}$ & $\begin{array}{c}\text { Methyl esters } \\
\text { Conversion } \\
(\%), \text { Castor oil }\end{array}$ & $\begin{array}{c}\text { Methyl esters Conversion } \\
(\%), \text { Cottonseed oil }\end{array}$ & $\begin{array}{c}\text { Methyl esters } \\
\text { Conversion } \\
(\%), \text { Coconut oil }\end{array}$ \\
\hline 4 & 92 & 95 & 89 \\
\hline 6 & 94 & 96 & 93 \\
\hline 8 & 94 & 96 & 93 \\
\hline
\end{tabular}

Molar ratio of Methanol to Oil $=6: 1$, Catalyst $(\mathrm{KOH})=1 \%$ (by wt. of oil), Flow rate $=6 \mathrm{ml} / \mathrm{min}$, Temperature $=60^{\circ} \mathrm{C}$

Table 12. Effect of Reaction time on methyl ester conversion

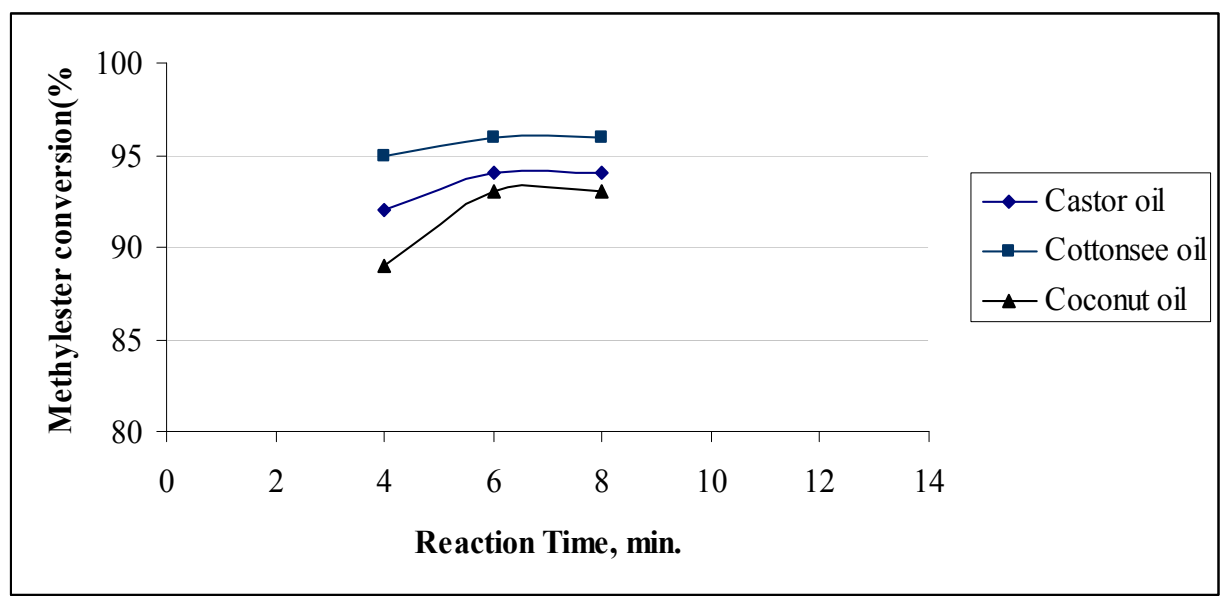

Optimum Reaction time $=6 \mathrm{~min}$.

Fig. 12. Effect of reaction time on methyl ester conversion 
The rate of transesterification depends on the time of reaction as shown in fig.12 The reaction was slow during the first few minutes due to time taken for mixing and dispersion of methanol with the triglycerides in the oil. However the rate of reaction increased steadily from $6 \mathrm{~min}$ of the reaction. The residence time of the reactants in the RD Column was $6 \mathrm{~min}$. at which the highest ME conversion was achieved. Thus the reaction time clearly influences the conversion rate of methyl esters.

\subsubsection{Effect of catalyst loading on methyl esters conversion}

The type of catalyst and the amount of catalyst has a great impact on formation of biodiesel. The adequate catalyst loading is necessary to obtain the maximum conversion of triglycerides to methyl esters. In the above experimentation, different types of catalysts with different catalyst loadings were utilized for transesterification reaction and their effects were studied. In the course of the tests, it is observed that addition of excess amount of catalyst, give rise to the formation of an emulsion, which has increased the viscosity and led to the formation of gel.

a. Effect of catalyst $(\mathrm{KOH})$ loading on methyl ester conversion

\begin{tabular}{|c|c|c|c|}
\hline $\begin{array}{c}\text { KOH } \\
\text { Catalyst loading } \\
\text { (wt.\%) }\end{array}$ & $\begin{array}{c}\text { Methyl esters } \\
\text { Conversion } \\
(\%), \text { Castor oil }\end{array}$ & $\begin{array}{c}\text { Methyl esters } \\
\text { Conversion } \\
(\%), \text { Cottonseed oil }\end{array}$ & $\begin{array}{c}\text { Methyl esters } \\
\text { Conversion } \\
(\%), \text { Coconut oil }\end{array}$ \\
\hline 1 & 80 & 92 & 95 \\
\hline 1.5 & 78 & 93 & 96 \\
\hline 2 & 60 & 93 & 96 \\
\hline
\end{tabular}

Methanol to oil molar ratio $=6$, Temperature $=60^{\circ} \mathrm{C}$, Catalyst loadings used for experimentation $=1 \%$, $1.5 \%$ and $2 \% \mathrm{KOH}$ by wt of oil

Table 13. Effect of catalysts loadings on methyl ester conversion

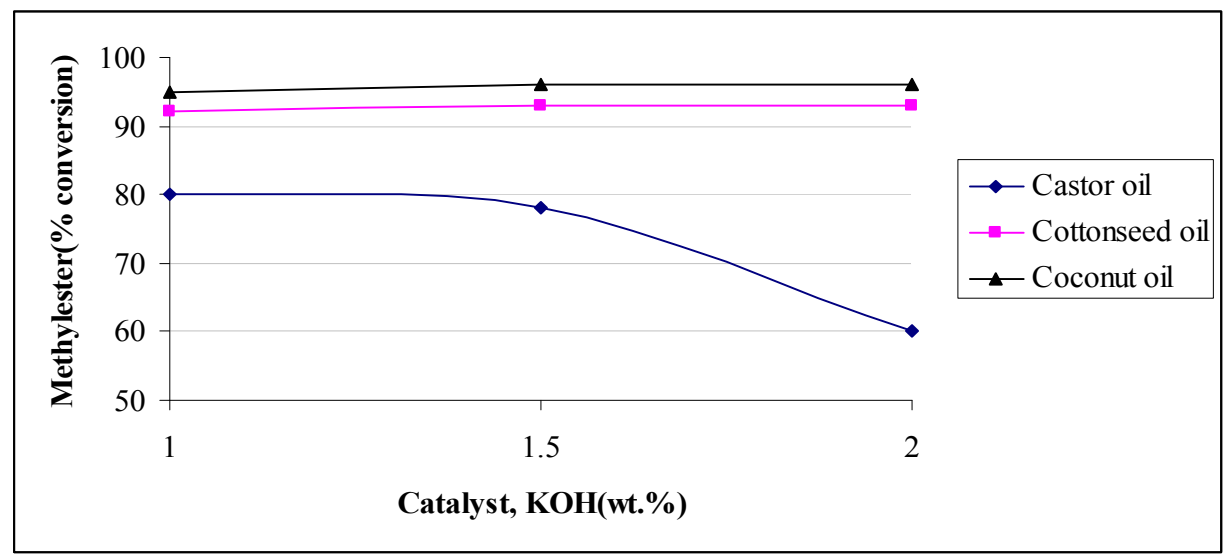

Fig. 13. Effect of catalyst (KOH) loading on Methyl ester Conversion

b. Effect of catalyst $(\mathrm{NaOH})$ loading on methyl ester conversion 


\begin{tabular}{|c|c|c|c|}
\hline $\begin{array}{c}\mathrm{NaOH} \\
\text { Catalyst loading } \\
(\text { wt. \%) }\end{array}$ & $\begin{array}{c}\text { Methyl esters } \\
\text { Conversion } \\
(\%), \text { Castor oil }\end{array}$ & $\begin{array}{c}\text { Methyl esters } \\
\text { Conversion } \\
(\%), \text { Cottonseed oil }\end{array}$ & $\begin{array}{c}\text { Methyl esters } \\
\text { Conversion } \\
(\%), \text { Coconut oil }\end{array}$ \\
\hline 0.5 & 72 & 89 & 94 \\
\hline 1 & 80 & 80 & 95 \\
\hline 1.5 & 78 & 91 & 96 \\
\hline 2 & 60 & 91 & 97 \\
\hline
\end{tabular}

Methanol to oil molar ratio $=6$, Temperature $=60^{\circ} \mathrm{C}$, Catalyst loadings used for experimentation $=0.5 \%$, $1 \%, 1.5 \%$ and $2 \% \mathrm{NaOH}$

Table 14. Effect of Catalyst $(\mathrm{NaOH})$ loadings on Methyl ester Conversion

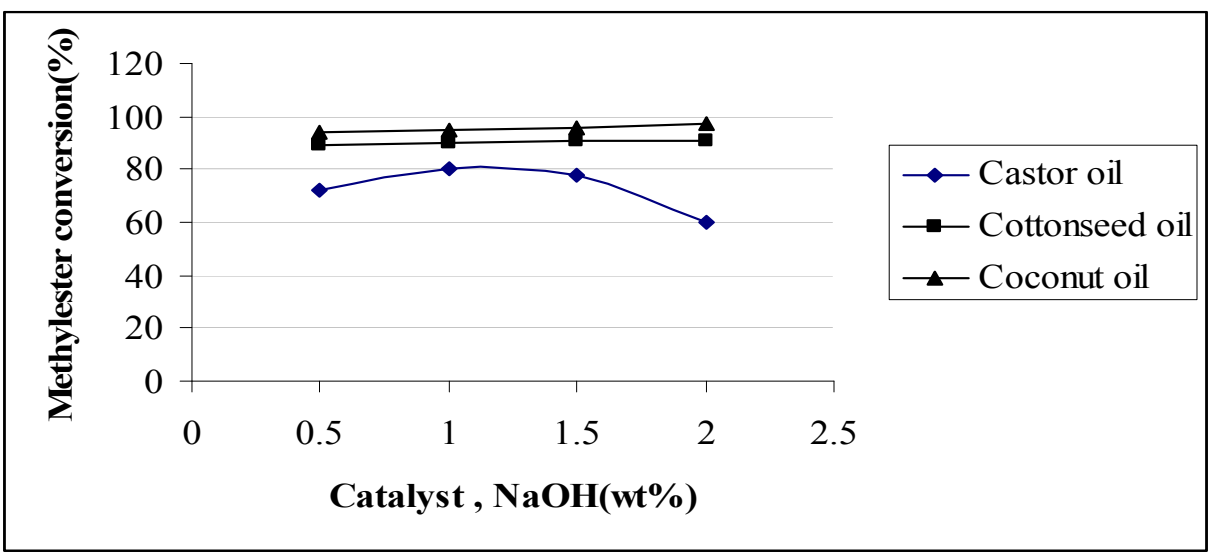

Fig. 14. Effect of catalyst $(\mathrm{NaOH})$ loading on Methyl ester Conversion

It can be seen that the conversion of triglyceride to methyl ester increased as the catalyst loading increased from 0.5 to $1 \mathrm{wt} . \%$. However, with the increase of the catalyst loading from $1 \%$ to $2 \mathrm{wt} . \%$, the conversion of triglyceride to methyl ester decreased. Since the conversions of triglycerides to methyl esters did not change significantly for the catalyst loadings from $1 \mathrm{wt} . \%$, the optimum catalyst loading for this reaction was $1 \mathrm{wt} . \%$.

c. Effect of catalyst (Amberlyst-15) loading on Methyl ester Conversion

\begin{tabular}{|c|c|c|c|}
\hline $\begin{array}{c}\text { Amberlyst-15 } \\
\text { Catalyst loading } \\
\text { (wt.\%) }\end{array}$ & $\begin{array}{c}\text { Methyl esters } \\
\text { Conversion } \\
(\%), \text { Castor oil }\end{array}$ & $\begin{array}{c}\text { Methyl esters } \\
\text { Conversion } \\
(\%), \text { Cottonseed oil }\end{array}$ & $\begin{array}{c}\text { Methyl esters } \\
\text { Conversion } \\
(\%), \text { Coconut oil }\end{array}$ \\
\hline 3 & 89 & 90 & 88 \\
\hline 4.5 & 77 & 80 & 76 \\
\hline 6 & 56 & 65 & 60 \\
\hline
\end{tabular}

Methanol to oil molar ratio $=6$, Reaction temperature $=60^{\circ} \mathrm{C}$, Reaction time $=1.5 \mathrm{hrs}$

Table 15. Effect of catalyst (Amberlyst-15) loading on Methyl ester Conversion 


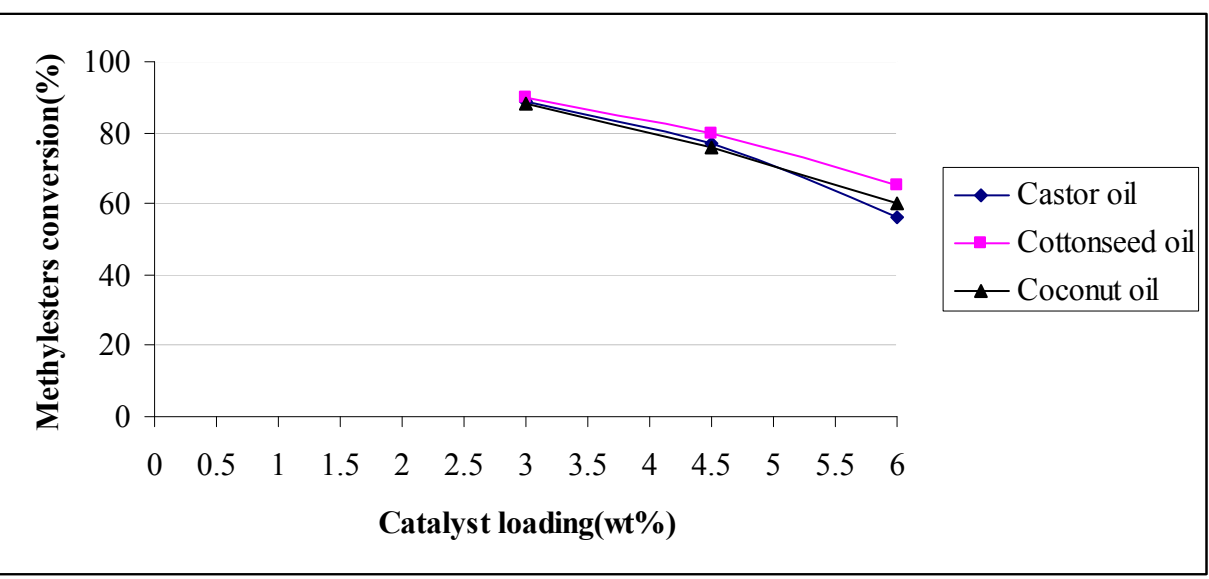

Optimum catalyst loading $=3 \mathrm{wt} \%$

Fig. 15. Effect of catalyst (Amberlyst-15) loading on Methyl ester Conversion

It can be observed that there was no rise in ME conversion when catalyst loading was increased from 3 to $6 \mathrm{wt} \%$. The highest conversion was achieved at catalyst loading of $3 \mathrm{wt} \%$.

\subsubsection{Effect of reaction time on methyl ester conversion using amberlyst $\mathbf{- 1 5}$ catalyst}

Amberlyst-15 a solid acid catalysts been studied for transesterification for production of methyl esters. However, mild reaction conditions are necessary to avoid degradation of the catalyst. At a relatively low temperature $\left(60^{\circ} \mathrm{C}\right)$, the conversion of castor, cottonseed and coconut oil was reported to be only between $2 \%$ to $5 \%$, when carrying out the reaction at atmospheric pressure and a 6:1 methanol-to-oil initial molar ratio.

\begin{tabular}{|c|c|c|c|}
\hline $\begin{array}{c}\text { Reaction } \\
\text { Time(hrs) }\end{array}$ & $\begin{array}{c}\text { Methyl esters } \\
\text { Conversion } \\
(\%), \text { Castor oil }\end{array}$ & $\begin{array}{c}\text { Methyl esters } \\
\text { Conversion } \\
(\%), \text { Cottonseed oil }\end{array}$ & $\begin{array}{c}\text { Methyl esters } \\
\text { Conversion } \\
(\%), \text { Coconut oil }\end{array}$ \\
\hline 0.5 & 60 & 65 & 55 \\
\hline 1 & 76 & 79 & 74 \\
\hline 1.5 & 80 & 85 & 82 \\
\hline 3 & 72 & 80 & 66 \\
\hline 3.5 & 65 & 62 & 52 \\
\hline 4 & 56 & 50 & 60 \\
\hline
\end{tabular}

Methanol to oil molar ratio $=6$, Reaction temperature $=60^{\circ} \mathrm{C}$, Catalyst loading $=3 \mathrm{wt} . \%$ Amberlyst- 15

Table 16. Effect of Reaction time on Methyl ester Conversion using Amberlyst -15 Catalyst

During the initial 30 minutes reaction time the percent conversion was less. But as the reaction time progressed the conversion of triglycerides to methyl esters was increased till further one hour. After $1.5 \mathrm{hrs}$ of reaction time, there was no significant rise in conversion. But the ME conversion decreased after $1.5 \mathrm{hrs}$. So, $1.5 \mathrm{hrs}$ is obtained as the optimum reaction time for this study. 


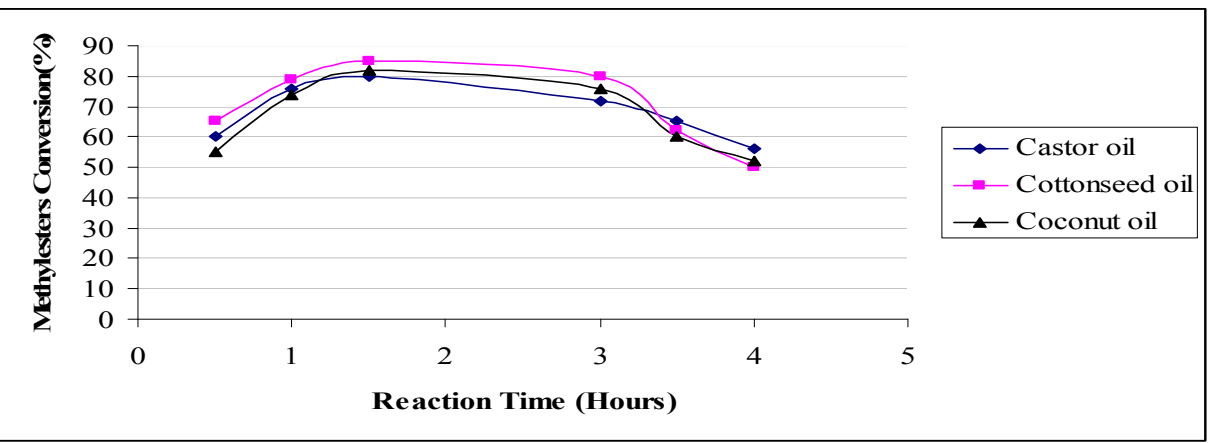

Optimum reaction time $=1.5$ hours

Fig. 16. Effect of reaction time on Methyl ester Conversion using Amberlyst -15 Catalyst

\subsubsection{Effect of methanol to oil molar ratio on methyl ester conversion using Amberlyst-15 catalyst}

\begin{tabular}{|c|c|c|c|}
\hline $\begin{array}{c}\text { Methanol-t-oil molar } \\
\text { ratio }\end{array}$ & $\begin{array}{c}\text { Methyl esters } \\
\text { Conversion } \\
(\%), \text { Castor oil }\end{array}$ & $\begin{array}{c}\text { Methyl esters } \\
\text { Conversion } \\
(\%), \text { Cottonseed oil }\end{array}$ & $\begin{array}{c}\text { Methyl esters } \\
\text { Conversion } \\
(\%), \text { Coconut oil }\end{array}$ \\
\hline 6 & 89 & 92 & 90 \\
\hline 9 & 76 & 84 & 77 \\
\hline 12 & 44 & 73 & 39 \\
\hline
\end{tabular}

Reaction time $=1.5 \mathrm{hrs}$, Reaction temperature $=60^{\circ} \mathrm{C}$, Catalyst loading $=3 \mathrm{wt}$. \% Amberlyst-15

Table 17. Effect of methanol to oil molar ratio on Methyl ester conversion using Amberlyst15 catalyst

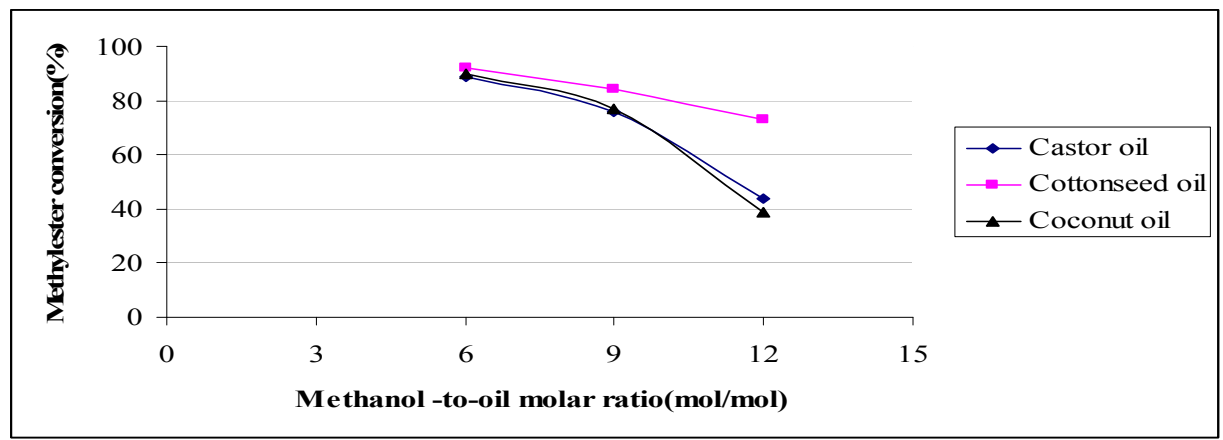

Optimum methanol to oil molar ratio $=6: 1$

Fig. 17. Effect of methanol to oil molar ratio on methyl ester conversion using Amberlyst-15 catalyst

It can be observed that there was no rise in ME conversion when methanol to oil molar ratio was increased from 6:1 to 12:1 .The highest conversion was achieved at methanol to oil molar ratio of $6: 1 . S o$, it is considered as optimum methanol to oil molar ratio. 


\subsubsection{Evaluation of column operating conditions}

Effect of reaction temperature on methyl ester conversion

\begin{tabular}{|c|c|c|c|}
\hline Temperature $\left({ }^{\circ} \mathrm{C}\right)$ & $\begin{array}{c}\text { Methyl esters } \\
\text { Conversion } \\
(\%), \text { Castor oil }\end{array}$ & $\begin{array}{c}\text { Methyl esters } \\
\text { Conversion } \\
(\%), \text { Cottonseed oil }\end{array}$ & $\begin{array}{c}\text { Methyl esters } \\
\text { Conversion } \\
(\%), \text { Coconut oil }\end{array}$ \\
\hline 55 & 89 & 84 & 90 \\
\hline 60 & 92 & 96 & 96 \\
\hline 65 & 94 & 97 & 96 \\
\hline
\end{tabular}

Molar ratio of Methanol to Oil $=6: 1$, Catalyst $(\mathrm{KOH})=1 \%$ (by wt. of oil), Flow rate $=6 \mathrm{ml} / \mathrm{min}$, reaction time $=6 \mathrm{~min}$

Table 18. Effect of reaction temperature on methyl ester conversion

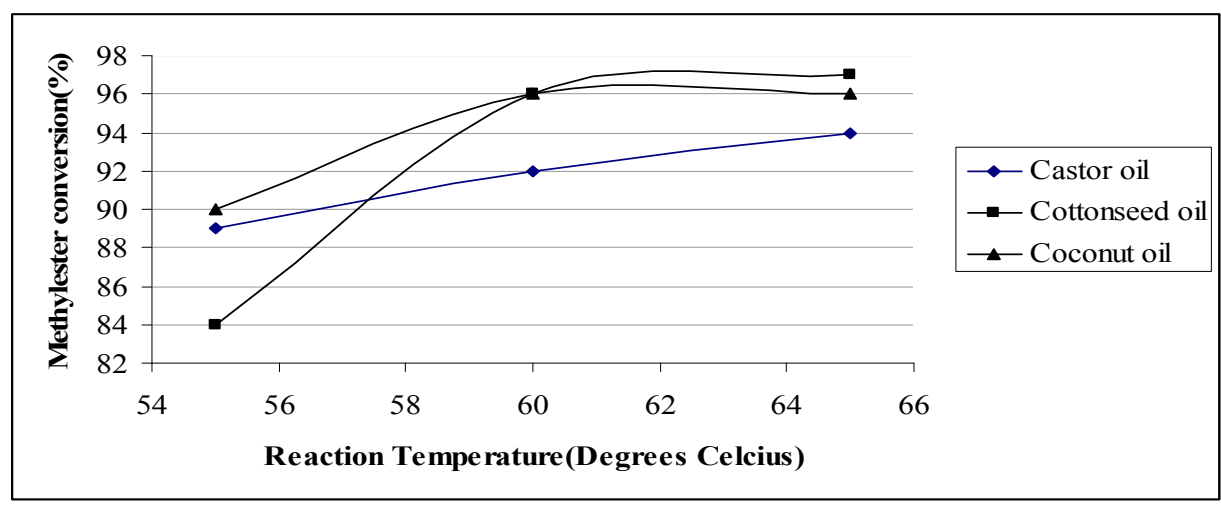

Optimum reaction Temperature $=60^{\circ} \mathrm{C}$

Fig. 18. Effect of Temperature on Methyl ester conversion (\%)

The effect of temperature on methyl ester conversion was studied by transesterification at different temperature i.e. $55{ }^{\circ} \mathrm{C}, 60{ }^{\circ} \mathrm{C}$ and $65{ }^{\circ} \mathrm{C}$. It was observed that the conversion increased with increase in temperature from $55^{\circ} \mathrm{C}$ to $60^{\circ} \mathrm{C}$. But there was no significant rise in conversion after $60{ }^{\circ} \mathrm{C}$ upto $65{ }^{\circ} \mathrm{C}$. So, the optimum value of temperature for this transesterification reaction was considered as $60^{\circ} \mathrm{C}$.

\subsubsection{Effect of reboiler temperature on methyl ester content of the product}

The function of reboiler is to vaporize the residual methanol present in the liquid reaching the bottom of the column. At steady state, the boiling-up rate of methanol is determined by the heat load on the reboiler, heat transfer efficiency and the amount of methanol in the reboiler. Methanol boils at $64.7^{\circ} \mathrm{C}$, however, according to the experiments, sufficient methanol vapors were generated only with reboiler temperature higher than $90^{\circ} \mathrm{C}$. Depending upon the methanol concentrations, therefore, reboiler temperature in the experimental design varied from $80^{\circ} \mathrm{C}$ to $120^{\circ} \mathrm{C}$ in order to produce smooth and consistent methanol vapor flow rates. It was found that the lower reboiler temperatures are favorable for better reactor performance. A possible reason is that with higher operating temperatures, the rates of soap formation increase more rapidly than that of transesterification. 


\begin{tabular}{|c|c|c|c|c|}
\hline $\begin{array}{c}\text { Time } \\
(\mathrm{hrs})\end{array}$ & $\begin{array}{c}\text { \%Methyl ester } \\
\text { at } 120^{\circ} \mathrm{C}\end{array}$ & $\begin{array}{c}\text { \%Methyl ester } \\
\text { at } 100{ }^{\circ} \mathrm{C}\end{array}$ & $\begin{array}{c}\text { \% Methyl ester } \\
\text { at } 90^{\circ} \mathrm{C}\end{array}$ & $\begin{array}{c}\text { \% Methyl ester } \\
\text { at 85०C }\end{array}$ \\
\hline 0 & 0 & 0 & 0 & 0 \\
\hline 1 & 25 & 34 & 10 & 33 \\
\hline 2 & 44 & 55 & 28 & 63 \\
\hline 3 & 56 & 67 & 49 & 68 \\
\hline 4 & 62 & 74 & 68 & 70 \\
\hline 5 & 66 & 78 & 80 & 72 \\
\hline 6 & 68 & 80 & 87 & 72 \\
\hline 8 & 68 & 83 & 90 & 75 \\
\hline 10 & 66 & 86 & 91 & 75 \\
\hline 12 & 66 & 88 & 93 & 73 \\
\hline 14 & 67 & 87 & 92 & 74 \\
\hline 15 & 67 & 87 & 92 & $\mathrm{~K}$ \\
\hline
\end{tabular}

Molar ratio of Methanol to Oil $=6: 1$, Flow rate $=6 \mathrm{ml} / \mathrm{min}$, Reaction time $=6 \mathrm{~min}$., Catalyst $(\mathrm{KOH})=1 \%$ by wt. of oil)

Table 19. Effect of reboiler temperature on methyl ester content of the product
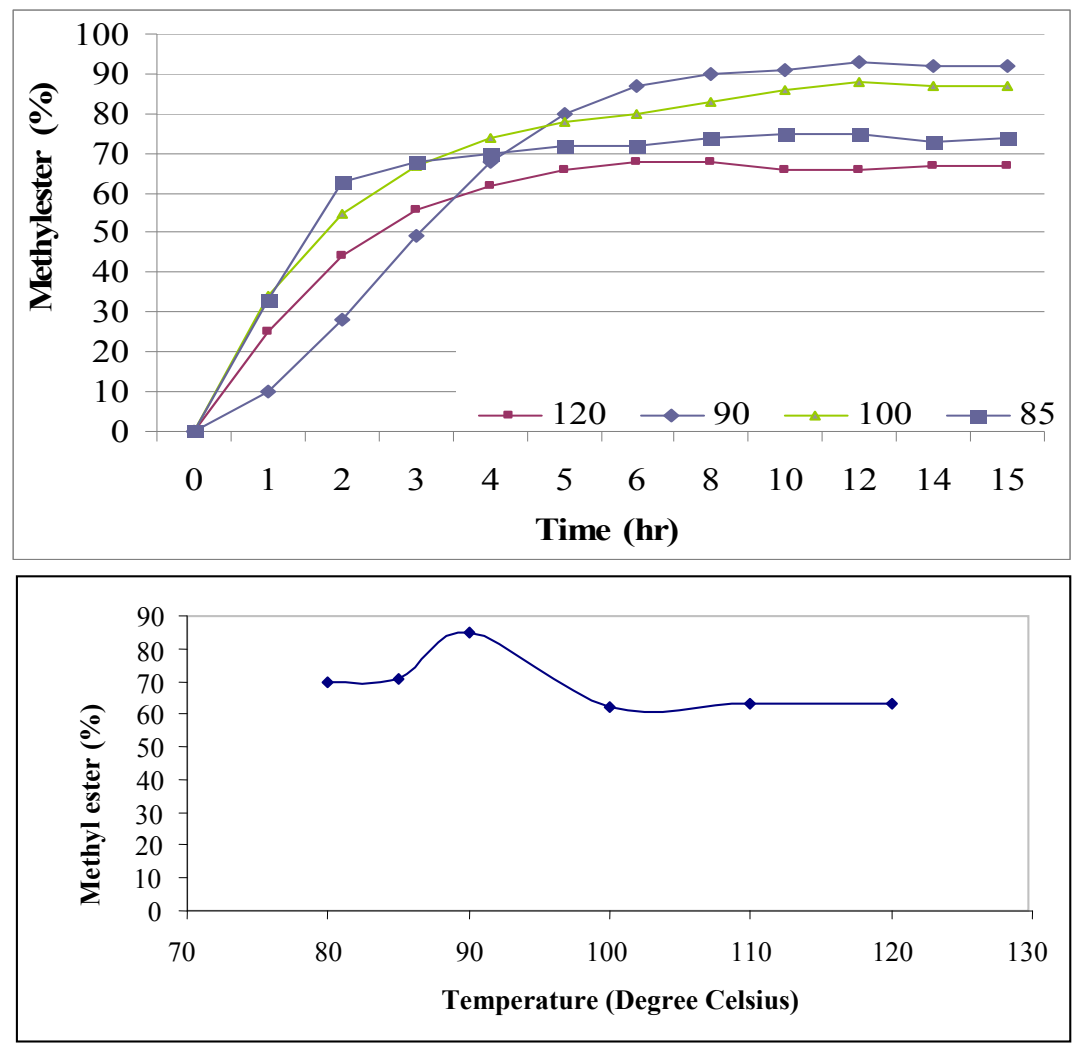

Fig. 19. The effect of the reboiler temperature on methyl esters content in product 


\subsubsection{Biodiesel yield}

The biodiesel yield was determined indirectly from the triglyceride as discussed in the materials and methods section. The percentage composition of the triglyceride consumed was assumed to be converted to methyl ester. Therefore, the amount of biodiesel produced was calculated from the difference in composition of triglyceride in the original oil and final biodiesel.

\section{Conclusions}

From the experimental investigation done in this research work, the following conclusions can be drawn:

Reactive distillation can be used as a techno economical process for synthesis of biodiesel from vegetable oil by transesterification process. The process proposed here can dramatically improve the economics of current biodiesel synthesis and reduce the number of downstream steps.

Using reactive distillation for synthesis of methyl ester has several advantages such as high unit productivity, up to 6-10 times higher than of the current process, lower excess alcohol requirements, reduced capital and operating costs, due to less units and lower energy consumption, Sulfur-free fuel, since solid acids do not leach into the product, no waste streams because no salts are produced. Also there is significant reduction in reaction time as well as in number of equipment units compared to that in conventional batch and continuous transesterification processes.

The feasibility of using mixture of two different vegetable oils was tested and it was found that coconut oil and cottonseed oil if mixed in equal proportion and used for transesterification reaction, the methyl esters conversion as high as $95 \%$ can be achieved.

From the experimental results the optimization of parameters obtained was as follows:

Transesterification reaction is affected by methanol to oil molar ratio, catalyst loading, reaction temperature, flow rate of reactant streams, reaction time, mixing intensity. In the present study reaction was carried out using three values of Methanol to oil molar ratios (3:1, 6:1 and 9:1) for individual oils (castor, cottonseed and coconut oil) and $\mathrm{KOH}$ catalyst for synthesis of biodiesel the highest ME conversions obtained for castor, cottonseed and coconut oil transesterification were $68 \%, 72 \%$ and $88 \%$ respectively. The highest ME conversion was obtained for coconut oil in this case. Whereas by using the heterogeneous catalyst Amberlyst -15, the highest ME conversions obtained for castor, cottonseed and coconut oil transesterification were $89 \%, 92 \%$ and $90 \%$ respectively for methanol to oil molar ratio of $6: 1$.

Also the possibility of using mixed oils was investigated by using three seed oils in 3 different proportions, such as mixed oil 1 ( $50 \%$ castor oil $+50 \%$ cottonseed oil ), mixed oil 2 ( $50 \%$ castor oil $+50 \%$ coconut oil $)$ and mixed oil $3(50 \%$ coconut oil $+50 \%$ cottonseed oil).The highest ME conversion (95\%) was obtained for mixed oil 3 at methanol to oil molar ratio of 6:1.Thus the option of using mixed oils is feasible in case of scarcity of one of particular feed stock oil in particular region. Also the application can be further investigated to reduce the cost of production of biodiesel by using cheaper feed stocks in more proportion in mixed oil feed.

The flow rate of reactants has an impact on reaction rate of biodiesel production. Out of $5 \mathrm{ml} / \mathrm{min}, 6 \mathrm{ml} / \mathrm{min}$ and $7 \mathrm{ml} / \mathrm{min}$ flow rates of reactants to the $\mathrm{RD}$ column transesterification reaction. The highest ME conversion (96\%) was obtained for cottonseed oil at reactants flow rate of $6 \mathrm{ml} / \mathrm{min}$. 
For a practical and economic feasible transesterification process, it is necessary to limit the reaction time at a certain period. Longer reaction time could also permit reversible transesterification reaction to occur, which eventually could reduce the yield of fatty acid alkyl esters. Thus, optimization of reaction time is also necessary. In this study, the reaction time was varied from $4 \mathrm{~min}, 6 \mathrm{~min}$ and $8 \mathrm{~min}$. It was observed that the highest $\mathrm{ME}$ conversion $(96 \%)$ was obtained for cottonseed oil at $6 \mathrm{~min}$ reaction time. Whereas for heterogeneous catalyst, reaction times of $0.5,1,1.5,3,3.5$ and $4 \mathrm{hrs}$ using catalyst Amberlyst- 15 for Methanol to oil molar ratio 6:1, Reaction temperature of $60^{\circ} \mathrm{C}$, Catalyst loading of $3 \mathrm{wt} . \%$ were used and the highest ME conversion (85\%) was obtained for cottonseed oil after 1.5 hrs reaction time. There was no significant rise in conversion rate after $1.5 \mathrm{hrs}$.

The catalyst plays an important role in transesterification reaction. The type and quantity of catalyst usually depend upon the quality of feed stock and method applied for transesterification. Three values of catalyst loadings of 1, 1.5 and $2 \mathrm{wt} \% \mathrm{KOH}$ were used for Methanol to oil molar ratio 6:1 at $60{ }^{\circ} \mathrm{C}$. The highest ME conversion (96\%) was observed for coconut oil at $1.5 \mathrm{wt} \% \mathrm{KOH}$ catalyst loading.

Similarly the second homogeneous catalyst $\mathrm{NaOH}$ also resulted in the same conversion for the same experimental conditions. Whereas the heterogeneous catalyst Amberlyst- 15 was used in three catalyst loadings of 3, 4.5 and $6 \mathrm{wt} \%$ Amberlyst- 15 for Methanol to oil molar ratio of $6: 1$, Reaction temperature of $60^{\circ} \mathrm{C}$, Reaction time of $1.5 \mathrm{hrs}$, the highest ME conversion (90\%) was obtained for cottonseed oil at 3wt \% Amberlyst- 15 catalyst loading.

The transesterification was carried out at reaction temperatures of 55,60 and $65^{\circ} \mathrm{C}$ for individual oils-castor, cottonseed and coconut oil and the highest ME conversions obtained for castor, cottonseed and coconut oil transesterification were 92\%, 96\% and 96\% respectively for $60^{\circ} \mathrm{C}$ temperature using $\mathrm{KOH}$ catalyst. For homogeneous catalyst, moderate reaction temperature is enough to commence the reaction whereas for heterogeneous catalyst the operating temperature varies depending upon activation energy and conditions to produce the high yield of methyl esters. For $\mathrm{NaOH}$ catalyst the same optimum value of 60 ${ }^{\circ} \mathrm{C}$ temperature was obtained in batch transesterification process with maximum ME conversion of $96 \%$.

The sufficient methanol vapors were generated only with reboiler temperature higher than $90^{\circ} \mathrm{C}$. Depending upon the methanol concentrations, therefore, reboiler temperature in the experimental design was varied from $80^{\circ} \mathrm{C}$ to $120^{\circ} \mathrm{C}$ in order to produce smooth and consistent methanol vapor flow rates. It was found that the lower reboiler temperatures are favorable for better reactor performance. A possible reason is that with higher operating temperatures, the rates of soap formation increase more rapidly than that of transesterification.

It was found that cottonseed oil resulted into maximum yield of biodiesel. Usually crude cottonseed oil contains palmitic acid (22- 26\%), oleic acid (15-20\%), linoleic acid (49-58\%) and approximately $10 \%$ mixture of arachidic acid, behenic acid and lignoceric acid, as well as about $1 \%$ sterculic and malvalic acids. In this study, the used crude cottonseed oil contained $24.60 \%$ of palmitic acid, $17.09 \%$ of oleic acid, and $50.50 \%$ of linoleic acid. Since higher amount of free fatty acids (FFA) $(>1 \% \mathrm{w} / \mathrm{w})$ in the feedstock can directly react with the alkaline catalyst to form soaps, which are subject to form stable emulsions and thus prevent separation of the biodiesel from the glycerol fraction and decrease the yield, it is better to select reactant oils with low FFA content or to remove FFA from the oil to an acceptable level before the reaction. Nevertheless, the FFA (calculated as oleic acid) content of the crude cottonseed oil used in this experiment was only $0.8 \%$, which was in an allowed level for being directly used for reaction with the alkaline catalyst to produce biodiesel. 
The castor oil showed yield of biodiesel less than that of cottonseed oil due to its high acid value. High acid value leads to neutralization of part of catalyst present thus producing soaps within the reaction medium which reduce mass transfer during the reaction. Also in basic medium, the hydroxyl group at C-12 of ricinoleic acid is converted into an alcohoxide derivative that can compete with the generation of methoxide species and compromise the conversion reaction. The Coconut oil contains approximately $92.1 \%$ saturated fatty acids, $6.2 \%$ monounsaturated fatty acids, $1.6 \%$ polyunsaturated fatty acids. Different fatty acids in coconut oil range from C6 - C18 carbon atom chains. It contains Lauric acid(over 50\%) higher in composition So, it was concluded that cottonseed oil was the most feasible feedstock among the three vegetable oil feed stocks under consideration for this study.

The production of biodiesel using transesterification by reactive distillation can be considered as technically as well as economically feasible process and its scale up at industrial level should be recommended to meet the future energy demand.

\section{Acknowledgement}

First of all, I wish to express my deepest gratitude to my supervisor Hon'ble, Dr.V.S.Sapkal, Vice Chancellor, Rashtrasant Tukadoji Maharaj Nagpur University, Nagpur, whose guidance, encouragement, wisdom, motivation, and expectations are indispensable to my achievements and will serve as a continuous inspiration for my future career.

My deepest thanks also go to respected Dr.R.S.Sapkal, Head, Department of Chemical Technology, Sant Gadgebaba Amravati University, Amravati, who gave me a lot of helpful ideas, suggestions, and discussions that contribute to the remarkable success achieved in this work.

No thanks are enough to Dr.N.B.Raut, Assistant Professor, Faculty of Engineering, Sohar University (Affiliated to Queensland University), Sultanate of Oman, Oman for his valuable direction, motivation and constant support in accomplishment of my research.

I would like to thank Dr.C.V.Rode, Dr.M.G.Sane, Senior Scientists from NCL, Pune for their technical support and guidance to my research. Thanks go to all the members in my laboratory as well as librarians of NCL, Pune, SGBAU, Amravati, SVIT, Nashik, KKW College of Engineering, Nashik for their help out in literature survey and analytical facilities in this research.

I also appreciate all my colleagues and other faculties at SVIT, Nashik, Prof.R.N.Vaidya, Brahma Valley College of Engineering, Nashik and Prof.M.G.Shinde, MET's Institute Of Engineering, BKC, Nashik for their precious direct and indirect assistance in this research work. I would thank lab assistants and staff of UDCT, Amravati for their kind cooperation during the experimentation phases. A special thanks goes to Mr.P.R.Wankhade for his valuable support during the experimentation phases at UDCT, Amravati.

Finally, I would like to thank my family and friends for their patience, motivation and admiration. My success is directly related to their love and strong support.

\section{References}

Chuaohuymak Pojanalai, Sookkumnerd Terasut, Kinetics of Homogeneous Transesterification Reaction of Palm oil and Methanol, Technology p. 1-6,2005.

Demirbas Ayhan, Biodiesel A Realistic Fuel Alternative. Trabzon: Springer-Verlag London Limited, 2008. 
Drapcho, Caye, Nghiem Phu Nhuan and Terry H.Walker. Biofuels Engineering Process Technology. New York Chicago San Fr: The McGraw-Hill Companies, Inc, 2008.

Kalayasiri, P., Jayashke, N. and Krisnangkura, K. "Survey of seed oils for use as diesel fuels." Journal of American Oil Chemical Society (1996): 73:471-474.

Noshadi I, A Review of Biodiesel Production Via Reactive Distillation AICHE Conference, Spring Session,2011

Richardson, Colson and. Particle Technology and Separation Processes. Newcastle: Library of Congress Cataloguing in Publication Data, 1991.

Sharma Y.C, Singh Bhaskar, A hybrid feedstock for a very efficient preparation of biodiesel, Technology, Volume, Pages 1267-1273, 2010

Sundmatcher, Kai and Achim Kienle. Reactive Distillation Status and Future Directions. Mhar. Achim Kienle Kai Sundmatcher. Megdeburg: Wiley-VCH, 2002.

Viswanathan B. and A.V.Ramaswamy, 'Selection Of Solid Heterogeneous Catalysts For Transesterification Reaction', National Centre for Catalysis Research, Indian Institute of Technology, Madras, Chennai 600036

Zhang Y, Dube M A, McLean D D, Kates D, analysis, Bioresource Technology 90 (3) p. 229240, 2003

http://www.crnindia.com

http:/ / www.castoroil.in

http:/ / www.mcxindia.com

http://www.biodiesel.org

http://www.coconutboard.nic.in

http://www.biodiesel.com

http://www.teriin.org

http://www.indexmundi.com 


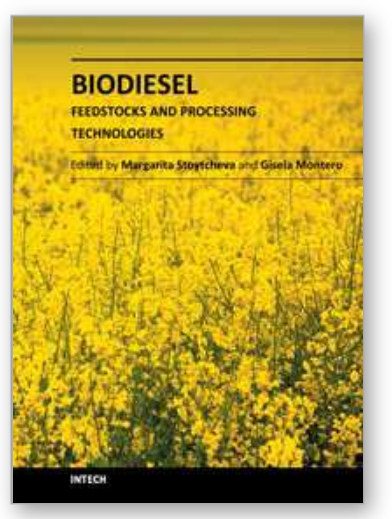

\author{
Biodiesel - Feedstocks and Processing Technologies \\ Edited by Dr. Margarita Stoytcheva
}

ISBN 978-953-307-713-0

Hard cover, 458 pages

Publisher InTech

Published online 09, November, 2011

Published in print edition November, 2011

The book "Biodiesel: Feedstocks and Processing Technologies" is intended to provide a professional look on the recent achievements and emerging trends in biodiesel production. It includes 22 chapters, organized in two sections. The first book section: "Feedstocks for Biodiesel Production" covers issues associated with the utilization of cost effective non-edible raw materials and wastes, and the development of biomass feedstock with physical and chemical properties that facilitate it processing to biodiesel. These include Brassicaceae spp., cooking oils, animal fat wastes, oleaginous fungi, and algae. The second book section: "Biodiesel Production Methods" is devoted to the advanced techniques for biodiesel synthesis: supercritical transesterification, microwaves, radio frequency and ultrasound techniques, reactive distillation, and optimized transesterification processes making use of solid catalysts and immobilized enzymes. The adequate and upto-date information provided in this book should be of interest for research scientist, students, and technologists, involved in biodiesel production.

\title{
How to reference
}

In order to correctly reference this scholarly work, feel free to copy and paste the following:

G.B.Shinde, V.S.Sapkal, R.S.Sapkal and N.B.Raut (2011). Transesterification by Reactive Distillation for Synthesis and Characterization of Biodiesel, Biodiesel - Feedstocks and Processing Technologies, Dr. Margarita Stoytcheva (Ed.), ISBN: 978-953-307-713-0, InTech, Available from: http://www.intechopen.com/books/biodiesel-feedstocks-and-processing-technologies/transesterification-byreactive-distillation-for-synthesis-and-characterization-of-biodiesel

\section{INTECH}

open science | open minds

\section{InTech Europe}

University Campus STeP Ri

Slavka Krautzeka 83/A

51000 Rijeka, Croatia

Phone: +385 (51) 770447

Fax: +385 (51) 686166

www.intechopen.com

\section{InTech China}

Unit 405, Office Block, Hotel Equatorial Shanghai

No.65, Yan An Road (West), Shanghai, 200040, China 中国上海市延安西路65号上海国际贵都大饭店办公楼405单元

Phone: +86-21-62489820

Fax: $+86-21-62489821$ 
(C) 2011 The Author(s). Licensee IntechOpen. This is an open access article distributed under the terms of the Creative Commons Attribution 3.0 License, which permits unrestricted use, distribution, and reproduction in any medium, provided the original work is properly cited. 